\title{
EL MAR Y EL PALADAR. EL CONSUMO DE PESCADOS Y MARISCOS EN CHILE DESDE LA INDEPENDENCIA HASTA 1930**
}

Este artículo proporciona un panorama de la provisión y consumo de pescado y mariscos en Chile. Se hace referencia a las especies disponibles en nuestra costa y las confusiones entre las mismas, a las dificultades para abastecer los mercados con producto fresco, los tempranos proyectos para la conservación de pescados y mariscos y la piscicultura, el volumen de las importaciones y las estimaciones de la producción local, además de las formas de preparación y preferencias de los consumidores. La evidencia disponible muestra que a medida que aumentaron las facilidades de transporte, la producción y consumo aumentó desde los comienzos del siglo XX.

Palabras clave: Pescados, mariscos, alimentación, comida.

This article provides a survey of fish and seafood supply and consumption in Chile. Reference is made to local species available in our coasts and the existing confusion between them. The difficulties in providing markets with fresh products, the early attempts to preserve fish and seafood and to establish fish farming, the volume of imports and estimates of local production, as well as the modes of preparation and consumer preferences, are considered in this study too. The available evidence shows that as transport facilities improved, production and consumption increased from the beginning of the Twentieth century.

Key words: Fish, seafood, diet, food.

Fecha de recepción: septiembre 2008

Fecha de aceptación: abril 2009

Pese a la extensión de sus costas, los pescados y mariscos no han tenido la importancia en la cultura gastronómica de Chile y en la dieta de sus habitantes, que les correspondería por la extensión de las mismas El propósito de este artículo es proporcionar antecedentes que expliquen esta situación, para lo cual se indagará acerca de la identificación y explotación de estos recursos alimenticios, las medi-

* Pontificia Universidad Católica de Chile. Correo electrónico: jcouyoum@uc.cl

* El presente trabajo es resultado del proyecto FONDECYT $\mathrm{N}^{\circ} 1070450$. El autor agradece los aportes de Carolina Sciolla y Angélica Manríquez, y la ayuda de Christine Gleisner, Karin Sánchez, Catalina Fuenzalida y Miriam Beltrán. A su vez, desea agradecer a los evaluadores anónimos del trabajo por sus correcciones y sugerencias. Correo electrónico: jcouyoum@uc.cl 
das adoptadas para su fomento y protección, el volumen de las importaciones de productos de mar, el aprecio que concitaban las distintas especies y los niveles y formas de consumo en el período estudiado. Por la amplitud misma del tema, y lo subjetivo de los elementos involucrados, como es el caso del gusto personal y colectivo, este trabajo no pretende hacer otra cosa que abrir senderos para un tratamiento más sistemático en el futuro.

\section{LOS RECURSOS PESQUEROS Y SU IDENTIFICACIÓN}

La riqueza de peces y moluscos de las costas de Chile era conocida desde antiguo, si bien el recurso era mal aprovechado. Diego de Rosales afirma que era inmensa "la copia de pezes que se crían assi en el mar como en los ríos, estanques y lagunas de estas Provincias de Chile, que ni sabemos sus nombres ni conocemos sus virtudes y calidades"1. Juan Ignacio Molina, escribiendo en Bolonia en los 1780, declara que "los pescadores chileños [sic] cuentan 76 especies distintas de peces [...] todos muy sanos y de sabor delicado". Advierte que, si bien "hablando rigurosamente sean distintos de todos los peces del Hemisferio Septentrional, no deja de haber un buen número, que no haciendo alto en algunas diferencias de poca monta, pueden pasar por individuos de las mismas especies" 2 . Otros, en cambio, eran propios de estas aguas. Felipe Gómez de Vidaurre concuerda en el número anterior de especies, mencionando al menos 17 que eran comunes a Europa, aunque, como veremos, esto no era necesariamente así $i^{3}$. El problema no era nuevo. Desde el tiempo del descubrimiento de América, los europeos se habían enfrentado a la dificultad de identificar las nuevas especies animales y vegetales encontradas en estas tierras.

La asimilación de peces, moluscos y crustáceos chilenos a sus congéneres europeos, hecha por Molina, ha dado origen a confusiones. La mención de la existencia en Chile del atún, el róbalo, la sardina o el bacalao, no significa que estos correspondan a la misma especie que se conoce como tal en España. Para distinguir entre uno y otro es preciso recurrir a su nombre científico, conforme aparecen en distintos estudios y catálogos ${ }^{4}$.

\footnotetext{
1 Diego de Rosales, Historia General del Reino de Chile, Flandes indiano, segunda edición íntegramente revisada por Mario Góngora, Santiago, Editorial Andrés Bello, 1989, tomo I, 267.

2 Juan Ignacio Molina, Compendio de la Historia Geográfica, Natural y Civil del Reyno de Chile, Primera parte que abraza la historia geográfica y Natural, Madrid, por Antonio de Sancha, 1788, 241.

3 Felipe Gómez de Vidaurre, Historia Geográfica, Natural y Civil del Reino de Chile, con introducción y notas por José Toribio Medina, Santiago, Ercilla, CHCh tomo XIV-XV, 1889, tomo I, 229-233.

4 Para este propósito hemos consultado las siguientes obras: Claudio Gay, Historia Física y Política de Chile, Zoología, tomos II y VIII, París, en Casa del Autor, 1848 y 1854; Edwyn C. Reed, Catalogue of the Fishes of Chile, Santiago, Imprenta Cervantes, 1897 (traducción de su "Catálogo de los peces chilenos", en Anales de la Universidad de Chile XCVIII, Santiago, $2^{\circ}$ semestre de 1897, 219-226); Luis Pomar, Account of the Fishing Industry in Chile read at the Sixth General Scientific Congress held in La Serena in January 1900, Santiago, Imprenta Moderna, 1901 (traducción de su "Memoria sobre la pesca en Chile", en Revista de Marina 28:165, Valparaíso, marzo de 1900, 232-283); Federico Albert, El Problema Pesquero en Chile. Reimpresión del Boletín de Bosques, Pesca i Caza, Santiago, Imprenta Kosmos, 1913; y Federico Ojeda P., Iconografía de los principales recursos pesqueros de Chile, Santiago, Ministerio de Economía, Fomento y Reconstrucción, Subsecretaría de Pesca, Instituto de Fomento Pesquero, 1982, 3 vols.
} 
El trabajo de identificación los peces y mariscos - "pescados de concha y costra" como los llama Diego de Rosales- iniciado por los cronistas coloniales, fue seguido por Claudio Gay y sus continuadores. Estos describieron otros nuevos, a la vez que distinguieron distintas especies bajo un nombre común ${ }^{5}$. Más interesante que las características morfológicas y su distribución geográfica son las noticias que estos autores aportan sobre su aceptación como alimento. El hecho de que Gay entregue el nombre vulgar de algunos hace pensar que eran más conocidos entre los pescadores, aunque no esté claro que hayan tenido un destino alimentario. Más útil en este sentido es el elenco de Federico Albert, inspector general de la Dirección de Bosques, Pesca y Caza, que distingue cuatro categorías de peces y mariscos: los que son comestibles, los "poco útiles", los incomibles y aquellos poco conocidos, que solo son identificados por su nombre científico.

De los peces mencionados ya por los cronistas, el más preciado era el róbalo (Eleginops maclovinus). Gómez de Vidaurre anota que "su carne es blanca, un poco transparente, de delicado sabor", especialmente cuando está muy fresco, mientras que "el róbalo seco es más gustoso que cualquier otro pez". Agrega que el más estimado provenía de la costa de Arauco, si bien otros consideraban que los de Chiloé eran aún más grandes y delicados ${ }^{6}$. Gay complementa estos datos ponderando su abundancia en toda la costa chilena y especialmente en el sur. Sin embargo, existirían al menos dos variedades: el Panguipes chilensis común en Valparaíso, que describe Gay, y el róbalo de piedra o róbalo negro (Nothothenia porteri) del sur de Chile, catalogado por Albert ${ }^{7}$.

La corvina (Cilus gilberti) era muy abundante y barata. Gómez de Vidaurre, que parece haber sido hombre de paladar fino, distingue los sabores de acuerdo al tamaño del ejemplar: cuando es grande, "su carne es consistente y basta, por lo que no tiene aprecio sino en las comunidades religiosas que siempre se alimentan de los que se vende en menos precio y más abundantemente en la plaza, pero ella joven es delicadísima y de una carne muy blanca".

La diferencia de sabor podría explicarse porque cambia de hábitat, y de alimento, según su edad ${ }^{8}$. Gay no distingue sabor según tamaño, pero concuerda con que "es un excelente pescado que se halla frecuentemente en la mesa del rico", y el capitán de navío Luis Pomar confirma que es "una de la principales delicadezas en la mesa de banquete" 9 .

Tanto Gay como los cronistas se refieren a la corvinilla, llamada también roncador o roncacho, común en Juan Fernández. Albert no la menciona, quizás porque, como declara Luis Castillo, biólogo de la Dirección de Pesca y Caza, también

\footnotetext{
5 Alonso de Ovalle, Histórica Relación del Reino de Chile, Santiago, Instituto de Literatura Chilena, 1969, 59-61; Rosales, op. cit., I, 271-274.

6 Gómez de Vidaurre, op. cit., I, 231.

7 Gay, Zoología, II, op. cit., 187, 165; Pomar, op. cit., 15, y 21, Reed, op. cit., 8-9; Albert, El Problema pesquero..., op. cit., 24, 28, 31, 34, 36.

8 Gómez de Vidaurre, op. cit., I, 231; Luis Castillo, "Contribución al estudio biológico de los peces marítimos comestibles de Chile (I)", en Boletín de Bosques Pesca y Caza (en adelante BBPC) I: 1, Santiago, julio de 1912, 40-42.

9 Gay, Zoología, II, op. cit., 195-196; Pomar, op. cit., 15-16.
} 
se daba el nombre de corvinilla a las corvinas pequeñas. Esta duda está resuelta y hoy se la considera como especie aparte, propia de los mares del norte ${ }^{10}$.

La lisa o liza (Mugil cephalus), que Gómez de Vidaurre asemeja al múgil de España, era común en toda la costa. El cronista distingue entre la que habita en aguas dulces y en el mar. La primera "es de sabor exquisito aun mejor que el de las mejores truchas"; en cuanto a la segunda, más grande, decía que si se comía de continuo "causa la sarna por lo que la desprecian"11. Albert y el naturalista Edwyn Reed registran además otra especie, la $M$. rammelsbergi. Gay califica a la lisa como "un pez de poca estima"; en cambio, William Howard Russell, que visitó el norte de Chile en compañía de J. T. North, consideraba que la lisa era el pescado más sabroso de Chile ${ }^{12}$. Un estudio de 1912 resuelve esta aparente contradicción: "La carne es blanca y blanda y de sabor delicado cuando se guisa a los dos días después de haber sido pescada; guisada antes de este plazo conserva un acentuado sabor a barro, del que contienen siempre sus intestinos una gran cantidad"13.

El lenguado (Paralichthys adspersus), que actualmente se considera un pescado fino, no recibe mayor atención de Gay y Pomar, quizás por la textura fibrosa de su carne que le atribuye Luis Castillo. Albert por su parte se limita a señalar que su carne blanca se consume mayormente fresca y que es apta para secarla ${ }^{14}$.

El pejegallo o pezgallo (Callorhynchus callorhynchus), llamado así por su cresta cartilaginosa, era poco apreciado, según Gómez de Vidaurre, por ser “de una carne suave pero desabrida, sana pero que exhala un olor poco agradable".

El mismo cronista menciona el tollo (Mustelus mento) como típico de las islas de Juan Fernández, agregando que se encuentra, con menos frecuencia, en el litoral de Chile. Comenta que "es mayor que el pejegallo, y de una carne más delicada y sabrosa, sin exhalar mal olor alguno ${ }^{15}$. Gay menciona varias especies de tollo, incluyendo entre ellas al pez espada, mientras Albert distingue cuatro variedades, siendo la más común el Galeorhynus mento que se encuentra en toda la costa ${ }^{16}$.

La vieja (Graus nigra) es calificada por Gay como "un excelente pescado"; Albert, en cambio, lo incluye entre los peces "poco útiles", pero menciona otras dos variedades comestibles: la vieja colorada o chancharro (Sebastes capensis) y la vieja negra (Graus nigra). Este último llegó a distinguir al menos dos variedades del jurel o furel, sin contar el jurel de Juan Fernández, que es una especie diferente ${ }^{17}$.

10 Gay, Zoología, II, op. cit., 184-185, 193-194; Castillo, "Contribución... (I)", op. cit., 39; Ojeda P., op . cit., I, 30 .

11 Gómez de Vidaurre, op. cit., I, 231.

12 Gay, Zoología, II, op. cit., 256-258; Reed, op. cit., 15; Albert, El problema pesquero..., op. cit., 17, 21, 24; William Howard Russell, A visit to Chile and the Nitrate Fields of Tarapacá, London, J \& S. Virtue, 1890, 141 y 143.

13 Castillo, "Contribución...(I)", op. cit., 33-34.

14 Ibid., 34; Gay, Zoología, II, op. cit., 332; Albert, El problema pesquero..., op. cit., 75.

15 Gómez de Vidaurre, op. cit., I, 232.

16 Gay, Zoología II, op . cit., 359-360; Albert, El problema pesquero..., op. cit, 21, 24, 28, 32, 34, 36, 38. Ojeda da el nombre de Mustelus mento al tollo, llamado también tollo blanco o tollo fino. Ojeda P., op. cit., tomo I, 2.

17 Gay, Zoología, II, op. cit., 233-237 y 276; Reed, op. cit., 13; Pomar, op. cit., 18-20; Albert, El problema pesquero..., op. cit., 21-40 y 78 . 
Otros peces identificados por los cronistas recibieron menos atención. Es el caso del dorado (Coryphaena hippurus), un pez de alta mar, incluido por Albert y Pomar entre los peces comestibles, pero calificado por otro biólogo como "perjudicial e inútil", en cuanto se comía los alevines de los salmones ${ }^{18}$.

Respecto del congrio, Gómez de Vidaurre lo incluye entre los peces semejantes a los de Europa, y quizás por ello, los cronistas no se ocuparon mayormente del mismo. Gay dice que era común en los mercados, aunque resultaba difícil conservarlo fresco. Señala que era más abundante en el norte, donde se salaba y secaba, y agrega que los pescadores distinguían tres tipos: "el congrio colorado, el negro y el plateado [el congrio dorado]. El primero es más común; el negro también abunda mucho y es más oscuro, con manchas blanquizas mayores y completamente sinuosas; es mucho menos apreciado como alimento [...] el plateado es el más estimado pero el más raro"19.

Luis Castillo reitera las opiniones de Gay sobre los méritos de las distintas variedades: "La carne de los congrios, [sea el colorado o el negro] [...] es excepcionalmente suave, blanda y sabrosa, con poquísimas y grandes espinas; por este motivo no ofrece peligros en la alimentación de los niños y de los enfermos".

Con todo, la consistencia del congrio colorado era más apropiada para su preparación "de preferencia frito y en estofado" y por ende se le prefería al congrio negro, de carne más blanda. Hacía ver, empero, que "si se le impregnaba con sal, no conserva ninguna diferencia ni de sabor ni de consistencia con la carne del congrio colorado" y podría adquirir el mismo valor ${ }^{20}$.

Gay no tuvo clara la distinta identidad de estas especies: "Dejemos a los naturalistas del país decidir si estas tres especies son verdaderamente distintas o variedades, o solo diferencias de edad". La confusión demoró en aclararse: Albert solo distingue entre el congrio negro (Genyepterus chilensis), que correspondería al descrito por Gay, y el colorado (Genypterus blacodes). En cambio, una clasificación más moderna da este nombre al congrio dorado; el Genypetus chilensis sería el congrio colorado descrito por Gay y el Genypterus maculatus correspondería al congrio negro ${ }^{21}$.

A la lista de especies identificadas por los cronistas se agregaron otras. Gay hace referencia a la jerguilla, que califica "uno de los mejores pescados", siendo de alto consumo tanto por su precio como por su calidad, a la que agrega la Aplodactylus punctatus llamada vulgarmente "reina de las jerguillas", pero que corresponde a un género diferente, mientras Albert, distingue tres variedades de la jerguilla propiamente tal, a la que agrega la jerguilla de Juan Fernández (Girella albostria-

18 Pomar, op. cit., 18; Albert, El problema pesquero..., op. cit., 37-40; Carlos Sage, "Estudio económico e industrial sobre los peces introducidos en Chile por la inspección Jeneral de Bosques Pesca y Caza", en BBPC I:5, noviembre de 1912, 307.

19 Gay, Zoología, II, op. cit., 339-340.

20 Luis Castillo, "Contribución al estudio biológico de los peces marítimos comestibles de Chile (II)", en BBPC I:2, agosto de 1912, 100-101.

21 Gay, Zoología, II, op. cit., 340; Albert, El problema pesquero..., op. cit., 27, 31, 33, 35, 41, 80; Ojeda P., op. cit., I, 70-71, II, 18. 
ta), calificada de "pez poco útil" 22 . La cabrilla o cabrilla española eran dos especies distintas que se confundían; era abundante en Valparaíso en tiempos de Gay y aún era común a fines de siglo ${ }^{23}$. El blanquillo destacaba al decir de Gay y Pomar por "un gusto muy delicado", quizás porque se alimentaba de crustáceos ${ }^{24}$.

La sierra abundaba especialmente en los meses de verano. Gay comenta que su carne era poco apreciada "a causa de sus numerosas espinas", pero alega que, no obstante, era apreciada por algunos. Una opinión semejante aparece en un libro de cocina de 1883 , que comenta en una nota que "es un pescado poco apreciado pero bien guisado es muy agradable". Dado que se conservaba mal, cuando se cogía en grandes cantidades se salaba y se vendía en los mercados fresca o seca ${ }^{25}$.

La cabinza (Isacia conceptionis) se confundía, según Gay, con la cabinza de Juan Fernández (Mendosoma fernandezianus), de género diferente. Más aún, Albert incluye otras dos especies bajo el nombre de cabinza: la Mendosoma caerulescens y la $M$. lineada ${ }^{26}$. La cojinova también se prestaba a confusiones. Modernamente se emplea este nombre tanto para la Seriolella porosa como para la Seriolella violacea, la que Gay y Reed conocían como hachita, según se la llamaba en Valparaíso. De la misma familia es la Seriolella caerulea, que corresponde a la actual cojinova austral y que Gay y Reed denominan también pampanito. Gay da el nombre de pampanito propiamente tal, al Stromateus stellatus, mientras Albert lo denomina Stromateus maculatus. Es posible que ello explique por qué "un pez poco estimado [que] se usa como carnada" según Gay, sea calificado de comestible por Albert y Pomar ${ }^{27}$. Algo semejante sucede con el bonito (Sarda chilensis) y el machuelo (Ethmidium maculatus). Gay señala que la carne del primero "era poco estimada", y que el segundo "se estima poco a causa de sus muchas espinas, por lo que solo se come frito" o se usa para carnada. Albert, empero, clasifica a ambos como peces comestibles y hoy se los incluye entre los recursos pesqueros ${ }^{28}$. Quizás el mejor ejemplo de la persistencia de estas confusiones es lo que sucede con el pez hacha: clasificada por Gay y Albert como Brama chilensis, se la asimila ac-

22 Gay, Zoología, II, op. cit., 156-161; Albert, El problema pesquero..., op. cit., 21, 24, 28, 31, 33; Baldomero Wolnitzky, "The Coast Fishery of the Province of Aconcagua", citado en The Chilean Committee of the Buffalo Exposition, The Fisheries of Chile, Santiago, Imprenta Moderna, 1901, 58.

23 Gay, Zoología, II, op. cit., 178-180; Pomar, op. cit., 18-20; Albert, El problema pesquero..., op. cit., 21, 24, 31, 33 .

24 Gay, Zoología, II, op. cit., 203-205, Pomar, op. cit., 18-20.

25 Gay, Zoología, II, op cit., 226-228; Pomar, op. cit., 17; Nuevo manual del Cocinero Práctico Chileno. Colección escogida de guisos y postres de las cocinas francesa, española, alemana italiana y chilena. Arreglado expresamente para el uso de las dueñas de casa chilenas. Contiene además gran número de recetas puestas al alcance de todos para postres de todas clases, dulces de almíbar, helados, frutas en aguardiente, etc., Valparaíso, Imprenta del Nuevo Mercurio, 1883, 41, notas.

26 Gay, Zoología, II, op. cit., 213-216; Pomar, op. cit., 18-20; Albert, El problema pesquero..., op. cit., 33 .

27 Gay, Zoología, II, op. cit., 239-249; Albert, El problema pesquero..., op. cit., 21, 24, 28, Pomar, op. cit., 18; Reed, op. cit., 11. El IFOP lo considera entre los recursos pesqueros (ver Ojeda P., op. cit., I, 48).

28 Gay, Zoología, II, op. cit., 223-225 y 322-323; Albert, El problema pesquero..., op. cit., 28, 37; Ojeda P., op. cit., I, 38; Instituto de Fomento Pesquero, Catálogo de recursos pesqueros de Chile, Santiago, Instituto de Fomento Pesquero, 1980, s. p. 
tualmente a la reineta y la palometa, clasificadas indistintamente como Brama australis o como Lepidotus australis ${ }^{29}$.

La sardina se hallaba en toda la costa desde la zona central hasta Magallanes. Gay y Castillo distinguían tres variedades: la Clupea sagax o sardina española, la Srattus fueguensis y la $C$. lycengraulis, estas últimas llamadas simplemente sardinas. Albert, en cambio, solo menciona dos, la común y la española, a las que da nombres diferentes. Gay señala que la sardina era consumida fresca y salada por los pescadores, y Pomar agrega que se la llevaba al mercado en una forma inapropiada para el consumo, no existiendo por entonces una industria conservera ${ }^{30}$.

La merluza común o pescada era, según Gay, "uno de los peces más abundantes en la costa de Chile", siendo salada por los habitantes ${ }^{31}$. Pereira Salas señala que esta no fue de consumo general hasta alrededor de 1760, cuando un francés, Luis Lison, enseñó a los chilenos a comerla frita $^{32}$. La pescada que se consumía en Santiago y Valparaíso era la pescada joven, ya que el pez adulto, de mayor tamaño y consistencia, no se acercaba a las playas ${ }^{33}$.

De entre los peces de agua dulce, Gómez de Vidaurre destaca al pejerrey, o "pezrey" como lo llama, que entonces era común en toda la costa y muy barato ${ }^{34}$. Al escribir sobre la familia Atherinidiae lo califica de "un excelente pescado" y agrega que "los jóvenes individuos de esta especie son los que se venden en los mercados de Valparaíso, en cierta época con el nombre de Mate (mote): los habitantes lo aprecian mucho y hacen tortillas con ellos" 35 . El citado cronista clasifica al cauque como una variedad de pejerrey de agua dulce, de mayor tamaño, "aunque su carne no es tan delicada como la de aquel", quizás porque se cogían en las lagunas y, por ende, tenían un gusto a cieno. Famosos eran los cauques o pejerreyes grandes de Aculeo, mencionados por el cronista, aunque para comienzos del siglo XX solo eran un recuerdo ${ }^{36}$. El bagre es mencionado por Gómez de Vidaurre, que lo califica de "pez feísimo", aunque su carne, un poco amarilla, es "una de las más delicadas que se pueden gustar entre los peces"37. Gay y Albert distinguen entre las especies fluviales y de mar pero no

29 Gay, Zoología, II, op. cit., 217; Albert, El problema pesquero..., op. cit., 33, 35; Ojeda la registra como Lepidotus australis (Ojeda P., op. cit., II, 30), mientras que la ficha para la reineta de la "Base de Datos sobre Recursos genéticos pesqueros, acuícolas y nativos", del Proyecto FIP 2006-52 del Fondo de Investigación Pesquera (http://www.laboratoriogenetica.cl/propuestafip/reineta.htm) la identifica como Brama australis.

30 Gay, Zoología, II, op. cit., 223-225, 320-321, 325-327; Albert, El problema pesquero..., op. cit., 21, 24, 28, 32, 34, 36; Pomar, op. cit., 17-18; Luis Castillo, "La fabricación de la sardina en aceite", en BBPC I:5, noviembre de 1912, 340-341.

31 Gay, Zoología, II, op. cit., 327-330.

32 Eugenio Pereira Salas, Apuntes para la historia de la cocina en Chile, Santiago, Editorial Universitaria, 1977, 49, 60 .

33 Luis Castillo, "Conducción del pescado fresco y su trasporte por ferrocarril", en $B B P C$ I:7, enero de $1913,484$.

34 Gómez de Vidaurre, op. cit., I, 231

35 Claudio Gay, Zoología, II, op . cit., 252-255.

36 Gómez de Vidaurre, op . cit., I, 235; Castillo, “Conducción del pescado...”, op. cit., 485.

37 Gómez de Vidaurre, op. cit., I, 235. 
precisan diferencias en su sabor ${ }^{38}$. El puye es mencionado por Gómez de Vidaurre; Gay y Pomar lo clasifican como una especie de aterina, y este último agrega "que solo habita en los ríos del sur" 39 . En cuanto a la trucha criolla o perca, Gay señala que "se encuentra en gran parte de las riberas de la República" y que las más gruesas y más recomendables se hallaban en las provincias del sur y en el río Duqueco, cerca de Los Ángeles. Pomar anota que su carne era muy preciada y que se vendía siempre a muy buen precio en los mercados ${ }^{40}$.

Algunos peces tenían hábitat particular. En Juan Fernández se capturaba una especie de bacalao (Hectoria oxigeneios). También era abundante en el archipiélago la murena o anguila, un pez fino de fácil pesca ${ }^{41}$. En la bahía de Coquimbo y sus cercanías se capturaba el pichihuén, exclusivo de la zona, donde se vendía fresco. Tanto Gay como Pomar ponderan su carne blanca, suave y blanda, muy apreciada y que se preparaba de diversas maneras ${ }^{42}$. En las costas de Tarapacá y Coquimbo era abundante la albacora o pez espada (Xiphias gladius). Gay, que la identifica como Lichia albacora, señala que en algunas pocas ocasiones solía ser capturada en Valparaíso, mientras Albert la sitúa en toda la costa. A fines de siglo era de consumo popular y se expendía en los mercados locales ${ }^{43}$.

Pese a la amplia gama de peces conocidos, el consumo se concentraba en unas pocas especies. Así, mientras la lista de peces comestibles elaborada por Albert supera los cincuenta, los pescados con cierta presencia en los mercados solo alcanzaban a once. Los testimonios arriba citados dan luces sobre las variedades preferidas: así se pondera la calidad del róbalo, de la lisa, el congrio colorado, el pejerrey, el cauque y la trucha del sur; mientras que en otros casos, como la jerguilla, la merluza, la corvina y la cabrilla, se hace alusión a su abundancia y, por implicancia, a su menor precio. Es probable, empero, que la variedad disponible fuera mayor por efecto de la diversidad de pescados vendidos bajo un mismo nombre y por la diferencia de la oferta en las distintas ciudades y pueblos ${ }^{44}$.

38 Gay, Zoología, II, op. cit., 296, 309-312, Albert, El problema pesquero..., op. cit., 21, 24, 27, $31,33,35$

39 Pomar, op. cit., 18; Gay, Zoología, II, op. cit., 255.

40 Gay, Zoología, II, op. cit., 146-147; Pomar, op. cit., 17; Albert, El problema pesquero..., op. cit., 16-17.

41 Pomar, op. cit., 16-17; Sociedad Nacional de Pesquería, Prospecto para la formación de una sociedad nacional de pesquería de las islas Santa María, Juan Fernández e Isla Grande de Chiloé, Santiago, Imprenta Chile, 1904, 25. Ni Albert ni Ojeda registran la murena, aunque sí la menciona Reed, que le da el nombre de culebra de mar. De su existencia actual da cuenta en Patricio Arana E. et al., Informe final. Monitoreo biológico pesquero de la langosta y cangrejo dorado en el archipiélago de Juan Fernández, Valparaíso, Pontificia Universidad Católica de Valparaíso, Facultad de Recursos Naturales, Escuela de Ciencias del Mar, 2006, 37, http://www.fip.cl/pdf/informes/inffinal\%20200448.pdf

42 Pomar, op. cit., 18

43 Gay, Zoología, II, op. cit., 230-231; Pomar, op. cit., 19; Albert, El problema pesquero..., op. cit., 31 .

44 La lista en Albert, El problema pesquero..., op. cit., 16-42. La nómina resulta inferior a las 71 variedades que indica Molina, pero este puede haber considerado variedades poco comestibles. 


\section{LOS MARISCOS Y SU EXPLOTACIÓN}

Tal como sucede con los peces, los cronistas coloniales dan cuenta de la abundancia de mariscos. Rosales se refiere al "pie de burro" o loco, a la taca o almeja, el pico de papagayo o picoroco, los choros, las apancoras y los erizos, aunque se interesa más en destacar sus formas que sus sabores ${ }^{45}$. A los ya mencionados, Molina agrega los piures, la jibia, los pulpos, las ostras, los comes, la centolla, la langosta de Juan Fernández y diversos tipos de camarones y jaibas ${ }^{46}$.

De los crustáceos chilenos el más afamado era -y sigue siendo- la langosta de Juan Fernández. Es particular al archipiélago, "desde donde la llevan frecuentemente a Valparaíso a causa de su buen gusto", dice Gay, siendo preferida a la langosta importada. La gran demanda redujo las existencias de langostas, por lo que, en 1896, se reguló su captura, fijándose una veda entre los meses de octubre y diciembre, aumentada luego a tres meses y medio ${ }^{47}$. En la década de 1890, y más tarde hacia 1918, se intentó su propagación en la costa de Valparaíso, Quintero y Concón, pero sin mayores resultados ${ }^{48}$. A la langosta le sigue en reputación la centolla, Lithodes antarctica, por entonces abundante en Chiloé, según Gay y Pomar, si bien no llegaba a competir con aquella por el costo del transporte ${ }^{49}$. En cuanto a las jaibas comestibles, el naturalista francés no aporta mayores noticias; Albert, en cambio, señala cinco especies comestibles: la jaiba blanca, de la cual distingue dos variedades, Platynochius purpurea y Ovalipes bipustulatus, la jaiba común o mora (Xantho planus), que era la más apetecida, la jaiba morada (Platycarcinus dentatus), la jaiba peluda grande (Cancer plebejis) y la jaiba talicuna, de la cual también hay dos especies, Epialtus dentatus e Inachus mitis ${ }^{50}$.

En cuanto a los camarones, hay que distinguir entre los de río y los de mar. De estos últimos, el más común era el Rhynchocinetes typus, conocido también como camarón de roca, camarón de playa o camarón de mar. Gay señala que se encuentra al borde de la costa de Valparaíso y en la zona central, siendo muy buscado por su buen sabor. Pomar agrega que los cardúmenes aparecen en ciertas épocas del año, siendo cogidos en canastos de mimbre y vendidos en los mercados ${ }^{51}$. Albert menciona también el langostino, que corresponde al actual langostino zanahoria, colorado, o

45 Rosales, op. cit., I, 271-274.

46 Molina, op. cit., I, 214-229.

47 Gay, Historia física y política de Chile, Zoología, tomo III, París, Casa del Autor, 1849, $205-$ 206; Federico Albert, La langosta de Juan Fernández. Extracto de la Revista Chilena de Historia Natural, $N^{\circ}$ 1, 2 y 3 de 1898, Valparaíso, Litografía e Imprenta Industrial, 1898, passim.

48 Ramón Briones Luco, Glosario de Colonización, Santiago, Imprenta Moderna, 1898, 266-267; Pomar, op. cit., 25-26; Albert, La langosta..., op. cit., passim.

49 Gay, Zoología, III, op. cit., 182-183; Pomar, op. cit., 26; Albert, El problema pesquero..., op. cit., 29 y 86.

50 Albert, El problema pesquero..., op. cit., 29; Wolnitzky, op. cit., 62. En la actualidad las distintas variedades comestibles y sus nombres científicos son la jaiba común (Cancer spp), jaiba limón (Cancer porteri), jaiba marmola (Cancer edwardsi), jaiba mora, (Homalaspis plana), jaiba panchote (Taliepus dentatus), jaiba patuda, (Taliepus marginatus), jaiba peluda o pachona (Cancer setosus), jaiba reina (Cancer coronatus) y jaiba remadora (Ovalipes trimaculatus).

51 Gay, Zoología, III, op. cit., 207-221; Pomar, op. cit., 26-27; Albert, El problema pesquero..., op. cit., 26, 29; Ojeda P., op. cit., III, 58. 
de bigotes rojos (Pleurocodes monodon), pero no hace referencia a la gamba (Haloporoides diomedeae) ni al langostino de Chile o langostino amarillo (Cervimunida jon), posiblemente porque son fauna de alta mar, fuera del alcance de los pescadores de entonces ${ }^{52}$. En cuanto al camarón de río, ponderado por Gay y Pomar, se encontraba en todo el país, siendo los mejores los de Huasco, Coquimbo y del río Aconcagua. La demanda de este producto era tal que, hacia 1900, se decía que el tamaño de los ejemplares capturados era pequeño porque no alcanzaban a llegar a su madurez ${ }^{53}$.

De los moluscos, el loco era muy abundante hasta fines del siglo XIX ${ }^{54}$. Los locos de Algarrobo parecen haber concitado especial preferencia, ya que figuran con denominación de origen en una receta de 1866. Pomar comenta "que es muy duro pero preparado con habilidad es un plato sabroso y agradable"55. Una consistencia parecida tienen la lapa y el chape, "frecuentes en la cocina chilena y tan estimadas como los locos". En cambio, los caracoles de mar, igualmente abundantes, no son tan sabrosos y no tenían demanda ${ }^{56}$. Tanto los locos como las lapas se daban en Chiloé, desde donde eran enviados a las provincias del norte, al menos a partir de los años $1850^{57}$.

El picoroco era calificado por María Graham como "el marisco más delicado que he probado" 58 . Los ejemplares que ella comió provenían de las rocas de Quintero, pero era común en toda la costa, desde Paposo hasta los archipiélagos de la Patagonia. Los más grandes provenían de Chiloé, donde alcanzaban un tamaño de 30 centímetros ${ }^{59}$.

Pomar señala que el choro era común a toda la costa. La variedad más preciada era el choro zapato (Choromytilus chorus), conocido como pellu por los mapuches, existiendo una variedad negra y otra amarilla. Fueron famosos los de la isla Quiriquina, pero ya en la década de 1880 se habían agotado por la sobreextracción; aún eran abundantes en los archipiélagos de Chiloé y de los Chonos, y se vendían frescos en los mercados cercanos a los lugares de extracción ${ }^{60}$. En un intento por proteger el recurso, se estableció un período de veda, que regía a fines del siglo pero que, al parecer, no se respetaba ${ }^{61}$. Avanzando en esta tendencia para proteger el recursos, la Ley de Pesca de 24 de junio 1907 autorizó al Estado para dar en arrendamiento, mediante subasta pública y por un período no mayor de veinte años, hasta la mitad de los bancos de moluscos existentes, con la obligación de renovarlos. Al amparo de esta disposición se dieron en arriendo a particulares los

52 Albert, El problema pesquero..., op . cit., 32-41; Ojeda P., op. cit., 54, 66, 68.

53 Gay, Zoología, III, op . cit., 211-212; Pomar, op . cit., 26-27.

54 Pomar, op . cit., 24-25; María Graham, Diario de mi residencia en Chile, Santiago, Editorial del Pacífico, 1950, 42.

55 Cuaderno de guisos y postres, Santiago, Imp. de El Independiente, 1865, 8; Pomar, op. cit., 24-25.

56 Wolnitzky, op. cit., 62-63.

57 Vicente Pérez Rosales, Ensayo sobre Chile, Introducción y notas de Rolando Mellafe Rojas, Santiago, Ediciones de la Universidad de Chile, 1986, 187.

58 Graham, op. cit., 42; Rosales, op. cit., I, 271.

59 Pomar, op. cit., 25.

60 Ibid., 22-23.

61 Pomar, op. cit., 22-23; Javier Barahona C., "Reglamentación de la pesca", en Revista de Marina I:1, Valparaíso, julio de 1885, 189-196. 
bancos de choros en la isla Santa María en 191262. La cholga o cholgua era abundante en toda la costa de Chile, pero las del norte hasta Colchagua eran de mala calidad. Mejoraba conforme se avanzaba hacia el sur y en Chiloé competía ventajosamente con el choro, sea fresca, seca o en conserva. Al igual que el choro, la cholga era exportada en pequeñas partidas desde Chiloé a las provincias del norte, al menos desde mediados del siglo XIX ${ }^{63}$. También se consumía el quilmahue, o chorito de miniatura como se le llamaba en Chile central, pero no era tan estimado como el choro y la cholga ${ }^{64}$.

Las tacas o almejas, en sus distintas variedades, eran abundantes en las playas desde Arica a Magallanes, donde se las recogía con rastrillos. Pomar las declara de excelente sabor, pero algo duras ${ }^{65}$. Maldonado señala que las tacas eran "poco apreciadas en el archipiélago [Chiloé], no obstante que esos moluscos son los más sabrosos", y solo se comerciaban en la región de Los Payos, al sur de Chonchi. Pérez Rosales, en cambio, menciona la exportación de pequeñas partidas a las provincias del norte, al menos desde los años $1850^{66}$.

El más delicioso de los moluscos chilenos, o al menos el más reputado, es la ostra. Claudio Gay describe tres tipos de ostras existentes en Chile a la fecha. La más conocida, y que se consume hasta hoy, es la Ostrea chilensis. Se encontraba desde poco al norte de la desembocadura del río Maullín hasta el estrecho de Magallanes y era especialmente abundante en las costas de Chiloé. Una segunda variedad, de tamaño similar a la anterior, era la Ostrea vinolenta, que se encuentra en Coquimbo y otros lugares, y cuyas "impresiones musculares" son descritas como "muy profundas y vivamente coloreadas de violado o heces de vino". También oriunda de Coquimbo era la Ostrea longiuscula, más grande que las anteriores, cuya concha era "oscuramente variada de pardo encarnadino sobre un fondo blanquisco". Era parecida a la ostra del Pacífico, cuyo cultivo ha sido posteriormente introducido precisamente en esa zona ${ }^{67}$.

Escribiendo en 1901, Alfredo Weber declara que las ostras de los bancos naturales de Chiloé eran tan buenas como las de Europa: "las mejores vienen de Melinka, de las islas Chauques, de la bahía de Ancud y la ensenada de Quetalmahue, de Calbuco, Maullín, etc."68. Maldonado también pondera sus virtudes: describe las ostras de Chiloé como "limpias, gordas y muy superiores", semejantes al tipo

62 Ley $\mathrm{N}^{\circ} 1.949$ del 24 de junio de 1907, en Ricardo Anguita, Leyes promulgadas en Chile desde 1810 hasta el $1^{\circ}$ de Junio de 1913, Tomo IV, Santiago, Imprenta, Litografía y Encuadernación Barcelona, 1913, 157; Arcadio Meza S., "Los yacimientos de moluscos. Subasta por cuenta del Estado", en $B B P C$ I:3, septiembre de 1912, 210.

63 Pomar, op. cit., 23; Perez Rosales, op. cit., 187.

64 Pomar, op. cit., 23.

65 Pomar, op. cit., 22; Roberto Maldonado, Estudios Geográficos e Hidrográficos sobre Chiloé, Santiago, Establecimiento Poligráfico Roma, 1897, 173; Albert, El problema pesquero..., op . cit., 23, 26, 30. Las denominaciones en la actualidad solo distinguen la Protothaca thaca y la Venus antiqua.

66 Maldonado, op. cit., 173; Pérez Rosales, op. cit., 187.

67 Gay, Zoología, VIII, op. cit., 281-288. Véase también su Atlas de la Historia Física y Política de Chile, París, Impr. de E. Thunot, 1854, tomo II, lámina "Malacología 5", figuras 1 a 3; Pomar, op. cit., 25; Ojeda P., op. cit., III, 16.

68 Alfredo Weber, “Apuntes sobre Chiloé", en Boletín de la Sociedad de Fomento Fabril (en adelante $B S F F$ ) XVIII, Santiago, 1901, 432. 
verdín de Ostende. Sin embargo, la técnica de explotación era lamentable; los ostreros chilotes

"no se molestan en lavar las conchas al levantarlas con la rastra, llegan al mercado y aún hasta las provincias centrales con una masa de fango, que asfixia al molusco, cuando no le comunica un hedor insoportable. Como consecuencia, las ostras del día desmerecen mucho en el mercado, con perjuicio de la industria y de los consumidores.

[...] sin observar método alguno, ejercían su oficio tan torpemente que han concluido por esterilizar los bancales naturales. No pensaban, como ahora no piensan, en el porvenir, y rastreaban sin conmiseración; elegían las conchas que apetecían, arrojando en seguida al agua los escombros que había levantado la rastra, y con tan absurdo procedimiento, terminaron por ahogar al molusco, que ha perecido por asfixia" 69

Estas malas prácticas, dice Maldonado, llevaron a la extinción de muchos bancos de ostras, como los de Quetalmahue y Punta Corona, si bien por entonces (1895) aún quedaban otros en los canales interiores de Chiloé, en las islas Guaitecas y en la desembocadura del río Maullín.

La preocupación por este recurso había llevado al gobierno en 1874 a prohibir la introducción y venta de ostras en el departamento de Valparaíso entre el $1^{\circ}$ de octubre y el $1^{\circ}$ de marzo de cada año ${ }^{70}$. Más que establecer un período de veda, Maldonado recomendaba reglamentar la recolección de este marisco y organizar en Chiloé "un instituto práctico de acuicultura", con profesores idóneos traídos de Inglaterra o Francia que enseñaran a los chilotes la forma de recolección y crianza del molusco ${ }^{71}$. Posteriormente se planteó la posibilidad de regular la explotación de los bancos de ostras, haciendo de ellos tres partes: uno para la extracción y dos para trabajarlos en los años siguientes de manera de permitir la renovación del molusco, a la vez de prohibir la extracción de ostras de un diámetro inferior a los cinco centímetros ${ }^{72}$. Como ya se dijo, la Ley de Pesca de 1907 dispuso el control de los yacimientos, y en 1912 se anunciaba la licitación de cien hectáreas de bancos de ostras de Quetalmahue, los que, por lo visto, aún eran provechosos ${ }^{73}$.

La navajuela ya era escasa en la costa del continente a fines del siglo XIX, pero aún abundaba en Chiloé, siendo muy estimada en su estado fresco. El come o comes, Pholas chiloensis, un marisco muy apreciado, se encontraba principalmente en el archipiélago, donde ya había dejado de ser abundante ${ }^{74}$. La macha era común en la costa desde Coquimbo a Chiloé hacia 1900. Uno de los ingredientes del curanto, se

69 Maldonado, op. cit., 169.

70 "Ordenanza que reglamenta la introducción y espendio de ostras en el departamento de Valparaíso", 7 de agosto de 1874, en Disposiciones Municipales. Leyes, Ordenanzas y Decretos sobre Servicios Municipales, Valparaíso, Imprenta de la Prefectura, 1912, 305-306.

71 Maldonado, op. cit., 169-170.

72 Weber, "Apuntes sobre Chiloé", op. cit., 432.

73 Meza S., "Los yacimientos de moluscos...", op. cit., 210-211. En los mínimos fijados para cada lote, las tres cuartas partes de la superficie por asignar tenían un mínimo de $\$ 450$ la hectárea. Es posible pensar que aquellos paños tasados a menor precio eran aquellos ya sobreexplotados.

74 Pomar, op. cit., 24; Albert, El problema pesquero..., op. cit., 30. Es interesante notar que Ojeda no incluye el comes entre los recursos pesqueros, a diferencia de la navajuela (Ojeda P., op. cit., III, 30), quizás porque había virtualmente desaparecido. 
la consumía fresca o seca en el archipiélago; no así en el norte, donde solo se comía fresca $^{75}$. El piur o piure era abundante desde Colchagua al sur, especialmente en la isla de Santa María, en Chiloé y en las islas del golfo de Penas. Molina dice que los naturales los comían "ya cocidos, ya tostados en su propio alvéolo", o lo secaban para enviarlo a Cuyo, donde era muy apreciado ${ }^{76}$. Pomar habla de un gran consumo de piures tanto en Chiloé como en el resto del país, quizás porque se le atribuían propiedades afrodisíacas superiores a las de las ostras ${ }^{77}$.

El erizo Loxechinus albus es mencionado ya por Diego de Rosales, quien pondera sus lenguas por ser "blandas y muy gustosas", además de atribuirles propiedades médicas $^{78}$. Para 1900, era abundante en toda la costa y las islas del sur de Chiloé, de donde provenían los mejores y más grandes ${ }^{79}$. Muy apreciados, se comían crudos o cocidos. La viajera Annie Brassey da cuenta de haber visto al costado del muelle de Coronel unas pilas de erizos sin las púas, atados con totoras de a tres. La gente los comía crudos "en cual estado se los considera más nutritivos; y cuando se asan en sus conchas o hechos en tortilla, son un artículo de comida favorito entre todas las clases sociales" 80 . El erizo también era recolectado por los pescadores de la costa de Aconcagua, donde los ejemplares alcanzaban $15 \mathrm{~cm}$ de diámetro, si bien "su número había disminuido notablemente a fines del siglo" 81 .

Este catastro de peces y mariscos comestibles conocidos, deliberadamente incompleto por lo demás, pone de manifiesto la dificultad para establecer la identidad de las especies que se consumían. El problema es menos marcado en el caso de los mariscos, por ser las diferencias morfológicas más evidentes, si bien, y tal como suele suceder ahora, se consumía en forma indistinta diferentes tipos de jaibas y langostinos. Esta confusión no solo se debe a la reclasificación de las mismas conforme avanzan los conocimientos, sino también al empleo de distintos nombres para un mismo pez y, al revés, el uso de un mismo nombre para distintos peces $^{82}$. A lo anterior se agregan las tentativas del pescadero de hacer pasar un pescado por otro, sea por desconocimiento o para venderlo con más facilidad y obtener mejor precio. Claudio Gay cuenta haber adquirido en Valparaíso para efectos científicos un ejemplar de Alosa cerulea, de la familia del machuelo, que "nos lo vendieron con el nombre de cabinza, sin duda por equivocación" 83 . El efecto acumulativo de estos factores hace difícil saber exactamente cuáles eran los productos que se consumían, un estado de cosas que subsiste hasta el presente.

El asunto de los nombres se vuelve a presentar en los manuales de cocina que circulaban en el medio local, tanto los provenientes del extranjero como los edita-

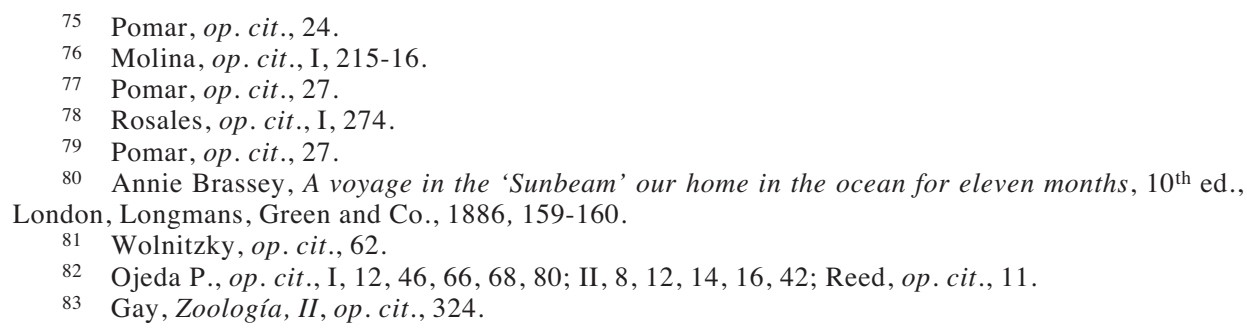


dos en Chile, y en los menús de banquetes $^{84}$. La semejanza de algunos peces chilenos con sus congéneres europeos, observada ya por Molina, hizo que los pescados que figuraban en los libros de cocina extranjeros tuvieran equivalencias reconocidas como más o menos válidas para efectos gastronómicos.

El polifacético Alberto Edwards, que se abocó a este asunto, declara que la anchoa europea era equivalente a la anchoveta chilena, aunque fuera una especie distinta. El atún, que aparece en los antipastos italianos que llegaban a Chile, era semejante al bonito, aunque este no tiene el sabor tan bueno como aquel, ni su tamaño. "El papel del atún lo representa en Chile, sobre todo en el norte, una especie vecina: el albacora o pez espada y algunos tiburones a que se suele dárseles el mismo nombre" 85 . La cabinza o caballa era equivalente al maquerel, la sarda de los españoles, el maquereau de los franceses y el mackerel de los ingleses, un pez famoso entre los antiguos latinos con el nombre de scomber. Advierte, sin embargo, que no existe en Chile el verdadero Scomber de Linneo, sino una especie análoga. En cuanto al lenguado chileno, este no tiene mucho que ver con

"los verdaderos lenguados españoles que no es sino el celebrado sole de los franceses. Nuestro lenguado se aproxima mucho más al turbot de los franceses o rodaballo de los españoles, tanto por la forma redonda de su cuerpo como por la calidad de su carne, muy inferior a los de los soles o lenguados europeos" $" 86$.

Volveremos sobre la terminología gastronómica de los pescados al tratar su consumo.

\section{LA PROVISIÓN DE PESCADO Y MARISCO}

En un país sin tradición marítima como Chile, la pesca se limitaba mayormente a las aguas litorales. Gómez de Vidaurre anota que la pesca se hacía en balsas hechas con cueros de lobo de mar inflados y atados, las que tenían un alcance limitado ${ }^{87}$. Este mismo sistema aún se usaba en la costa de Atacama y más al norte cuando Rodulfo Amando Philippi estuvo allí entre 1853 y $1854^{88}$. Por entonces, los botes y canoas pesqueras del litoral central eran algo más sólidos, pero su capacidad era apenas mayor, como se aprecia en un grabado de la costa de Constitución en el Atlas de Gay; quizás era similar a la de los botes actualmente en uso en tantas caletas de pescadores. Esta situación se prolongó hasta bien entrado el siglo XX. Un informe en el Boletín de la Sociedad de Fomento Fabril afirma que toda la

84 Sobre la difusión de los manuales de cocina en Chile, véase Carolina Sciolla y Ricardo Couyoumdjian, "La letra y la comida. Una aproximación a los manuales de cocina como un medio de renovación culinaria en Chile", en Boletín de la Academia Chilena de la Historia 116, Santiago, 2007, 275-309.

85 J. B. C. [Alberto Edwards], "Los pescados chilenos ante la dueña de casa", en Pacífico Magazine X, Santiago, segundo semestre 1917, 2-7. Agradezco la referencia a Pablo Díaz.

86 Ibid., 3.

87 Gómez de Vidaurre, op. cit., I, 232.

88 Rodulfo Amando Philippi, Viaje al desierto de Atacama hecho de orden del gobierno de Chile en el verano de 1853-54, Halle, Librería de Eduardo Antón, 1869, 28. 


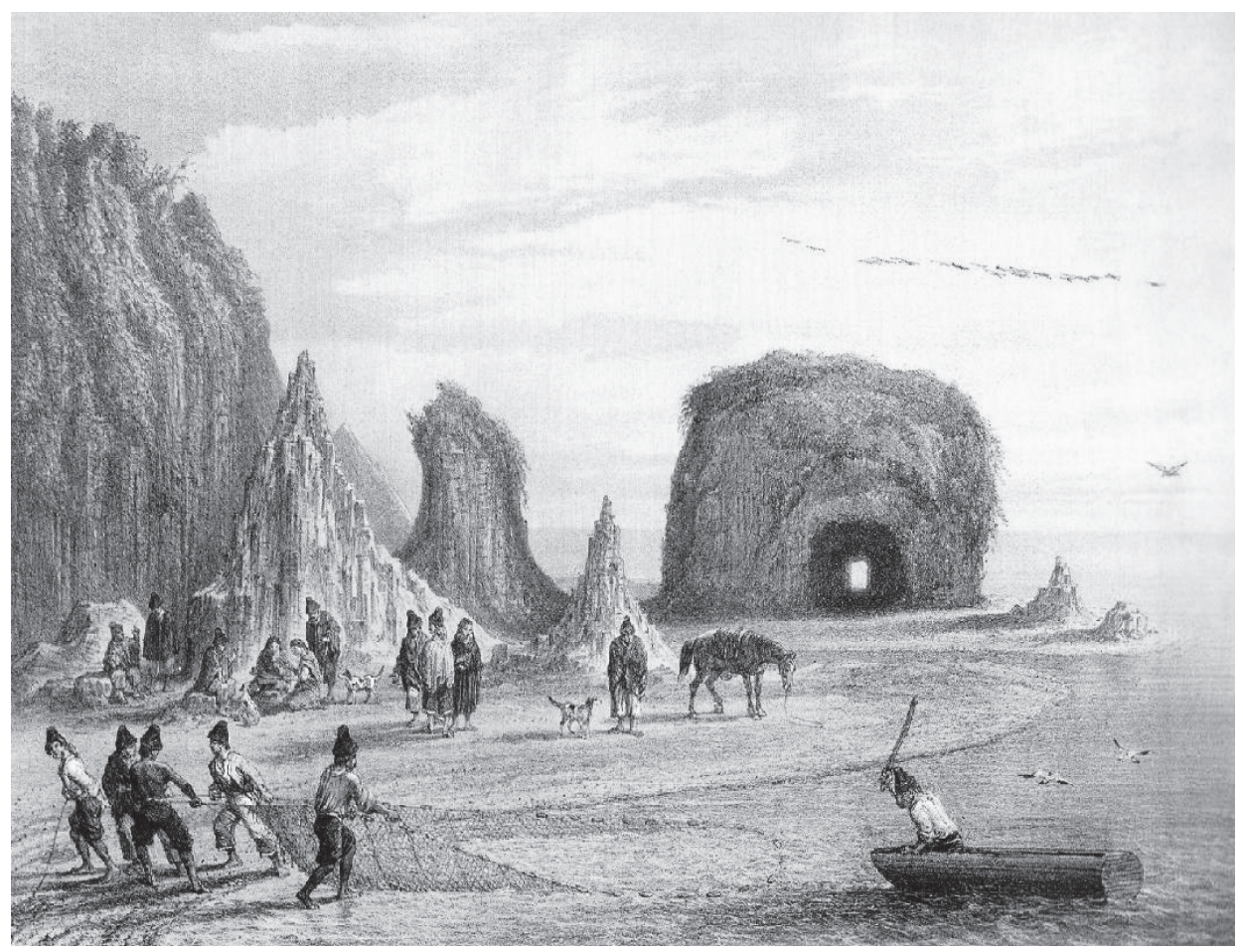

Pescadores en Constitución.

Lámina 37 del Atlas de la Historia Física y Política de Chile de Claudio Gay.

pesca en Chile "es de producción costina o sea de un campo de operaciones que nunca va más allá de 15 millas de la costa"89.

La pesca de mar se hacia con red, con espinel, con anzuelo de mano, o aun con tridente, según el tipo de pez: Gay y otros autores dan ejemplos de su empleo en cada caso $^{90}$. Al parecer, la mayoría de los pescadores tenía la práctica de pescar con anzuelo, usando habitualmente como carnada el jurel, la cabinza, la sierra, el blanquillo y la pescada, por ser estos de menor valor. En los ríos se usaban, además, diversos tipos de trampas, redes, rejillas y canastos. Pese a que estaba prohibido, había quienes pescaban con explosivos, una práctica fuertemente criticada por los daños causados al recurso. Un perjuicio semejante provocaba el empleo de rastras y otros medios semejantes para la recolección de mariscos, como vimos a propósito de las ostras ${ }^{91}$.

89 "La industria de la pesca en Chile", en BSFF XXXVII:8, agosto de 1920, 460.

90 Vg. Gay, Zoología, II, op. cit., 158, 165, 178-180, 195-196; Castillo, "Contribución...(II)", op. cit., 94-102; Wolnitzky, op. cit., 57.

91 Albert, El problema pesquero..., op. cit., 47-93, especialmente 69. 
Una zona rica en pesquería eran las aguas vecinas a Juan Fernández, desde donde, ya en el período hispano, se traía al continente el bacalao y otros pescados secos y, de manera especial, la langosta. Las aguas de las islas San Félix y San Ambrosio eran igualmente ricas, aunque mucho menos explotadas por razones de distancia ${ }^{92}$. La captura de la langosta en Juan Fernández tenía lugar entre abril y septiembre, cuando abandonaba las grandes profundidades para acercarse a las playas ${ }^{93}$. Hacia 1880, el suizo Alfredo de Rodt, arrendatario de la isla y subdelegado de la misma, había "establecido el transporte desde la isla a Valparaíso de langostas vivas y pescado en un buque especial de alta mar"94. A la vuelta del siglo, el número de langostas vivas llevadas a Valparaíso se calculaba en 250 unidades mensuales entre enero y agosto, existiendo una demanda bastante superior. En el puerto, las langostas se conservaban en las "lanchas viveras de ostras", hasta el momento de la venta ${ }^{95}$. Las técnicas para su extracción mejoraron en la segunda década del siglo XX, lo que debe haber contribuido a aumentar la escasez del recurso ${ }^{96}$.

Un tradicional productor de pescado y marisco era Chiloé. En el caso de los moluscos, estos eran recogidos cuando bajaba la marea, especialmente en las sizigias y la época de los equinoccios. Weber señala que en estas faenas se llenaban canastos de choros, cholgas, luche y cochayuyo, lo suficiente para comer varios días ${ }^{97}$. Sin embargo, había técnicas más refinadas. Roberto Maldonado (1895-96) se refiere a un tal Silvestre Navarro de Dalcahue, "uno de los hombres más prestigiosos de Chiloé", quien tenía en la playa vecina a su casa un cholcheñ o vivero, el que corresponde a un tramo de playa, despejado de piedras. Habilitado el espacio,

"se espera una de las grandes mareas; se marisca en las bancadas naturales, según las especies que más agraden al consumidor; se lavan las conchas, despojándolas de todo objeto extraño y se trasladan en seguida a la playa donde debe hacerse el cholcheñ. Calculando el nivel de las mareas chicas, se depositan los moluscos, según sus especies, en grupos separados, extendiéndolos sobre la playa sin recargarlos, para evitar la asfixia. Quedan, pues, así en un plano emergente, en donde el flujo y reflujo y el curso de las corrientes limpian el molusco, que engorda y adquiere un sabor más agradable" 98 .

Aunque la ventaja de los cholcheñes era reconocida "por las gentes previsoras y de buen gusto", su uso no estaba generalizado ${ }^{99}$. Otra forma de recoger mariscos en Chiloé era mediante chanchos: a semejanza de los franceses que usan puercos para recolectar trufas, "estos desentierran tacas (almejas) y antes que

92 Thaddaeus Peregrinus Haenke [atribuido], Descripción del Reyno de Chile, Santiago, Editorial Nascimento, 1942, 70; Pomar, op. cit., 19-20.

93 Gay, Zoología, III, op. cit., 205-206; Pomar, op. cit., 25; Sociedad Nacional de Pesquería, op. cit., 22 .

94 Alfredo de Rodt a Ministro del Interior, s.f, recibida en Santiago, 20 de agosto de 1881, AN. Ministerio de Obras Públicas, Volumen I.

95 Sociedad Nacional de Pesquería, op. cit., 23-24.

96 Arana et al., op. cit., 94-97.

97 Alfredo Weber S., Chiloé. Su estado actual, su colonización, su porvenir, Santiago, Imprenta Mejía, 1903, 148.

98 Maldonado, op. cit., 143-144.

99 Ibid., 141. 
puedan mascarlas, los muchachos les pegan en el hocico para que este largue la pieza" 100 .

Pese a lo limitado de la actividad pesquera, se produjo una disminución de los recursos marinos más apetecidos, como sucedió con la langosta, la ostra, el choro zapato, los erizos y los camarones de río de gran tamaño. Ya en 1885, la Sociedad Nacional de Agricultura lamentaba el agotamiento de la pesca. Julio Menadier, redactor de su Boletín, comparaba la abundancia de peces de antaño con la escasez actual: "la superabundancia anterior ha llegado a tal escasez, que hasta a orillas de nuestros grandes ríos se carece a menudo de pescados durante largos meses; fuera de tres o cuatro variedades, se han extinguido casi todas las demás de que dan cuenta los historiadores antiguos del país".

Es probable que esta publicación, destinada a promover la piscicultura en Chile y establecer temporadas de veda, exagerara la situación como una manera de presionar por la pronta adopción de medidas ${ }^{101}$. En todo caso, la caída de las existencias, destacada por algunos observadores, se debía a la manera ineficiente como se explotaba el recurso antes que a la pesca excesiva. De ahí el propósito de las autoridades de impulsar esta actividad, en el entendido de que se debía hacer en forma racional. Es así como mediante un decreto de 1895 se otorgaron incentivos para el establecimiento de colonias de pescadores extranjeros en diversas caletas, y se formularon propuestas para el mayor empleo de redes, de embarcaciones a vela y, ya a comienzos del siglo XX, de motores fuera de borda ${ }^{102}$. En el mismo sentido, la Ley de Pesca de 1907 acordó primas anuales de 15 pesos por tonelada de desplazamiento a las naves de bandera nacional ocupadas exclusivamente en esta actividad, más 10 pesos por cada tonelada de peces y mariscos frescos desembarcados. Al parecer, este incentivo no dio los resultados esperados, quizás porque, como afirmaba la Dirección de Bosques Pesca y Caza, las primas iban "siempre a las manos de los colectores, nunca a los pescadores"103.

La Ley de Pesca de 1925, que recoge las tendencias anteriores, mantuvo la concesión de primas a las embarcaciones pesqueras de cierto tamaño, que se financiaría con un impuesto a las capturas de las especies más preciadas. Al mismo tiempo se reglamentaba la veda de distintas especies y se fijaban tamaños mínimos para la captura. Los productos bajo el régimen de veda incluían ahora los salmones, las truchas, los pejerreyes, los bagres, los ostiones, cholgas y choritos, las centollas, las jaibas y los camarones de río, además de la langosta, el choro y la ostra ${ }^{104}$.

La preocupación por la baja actividad pesquera había surgido, al menos en parte, en los círculos navales, como lo atestigua la revisión de los primeros años de

\footnotetext{
100 Ibid., 361.

101 Julio Menadier, "Revista Piscícola", en Boletín de la Sociedad Nacional de Agricultura (en adelante BSNA) XVII:1, Santiago, 1885, 16-20.

102 "Concesiones para traer inmigrantes pescadores", en BSFF XXI: 7, 1 de julio de 1904, 300301; Adolfo Ortúzar, Le Chili de nos jours. Son commerce, sa production et ses ressources..., Le Havre, Imprimerie A. Lachevre, 1904, 13; Albert, El problema pesquero..., op . cit., 93-111.

103 Arcadio Meza S., "La industria de la pesquería", en BBPC I:2, agosto de 1912, 117; "E1 Ferrocarril Longitudinal y el abaratamiento del pescado", en BBPC I:8, febrero de 1913, 505.

104 República de Chile, Lei i reglamento de pesca marítima i fluvial, Santiago, s.p.d.i., 1925, 7-21.
} 
la Revista de Marina. Las propuestas para el fomento de la misma concordaban, por lo demás, con las tendencias proteccionistas en materia de comercio exterior, en cuanto se buscaba disminuir la importación de pescado seco. Escribiendo en 1899, el vicealmirante Luis Uribe declaraba que "en Chile el pescado ha sido y continúa siendo un artículo de lujo por su escasez y alto precio, solo al alcance de las clases acomodadas"105. Aunque esta afirmación no era válida para Chiloé y otras zonas costeras donde la pesca era abundante, en el resto de Chile el pescado solo llegaba a las principales ciudades del centro, en especial Santiago y Valparaíso. Si resultaba difícil conseguir buen pescado fresco en Santiago, más lo era en otras ciudades del interior, donde no formaba parte de la dieta. Estando en Victoria en 1890, Gustavo Verniory declara que no se comía pescado fresco: "no hay comunicación con el mar y el pescado de río no es apreciado". Con todo, más adelante agrega haber saboreado el bacalao a la vizcaína, pero hecho con pescado seco importado ${ }^{106}$. Una consideración similar hace Roberto Páez quien, al comentar un recetario ovallino del siglo XIX, señala que en las localidades del interior "no siempre abundaba el pescado fresco" y advierte que de las tres recetas de pescado, dos de ellas se preparaban con salmón en conserva ${ }^{107}$.

El obstáculo principal que presentaba el aumento del consumo de pescado fresco durante el siglo XIX era la dificultad para su transporte, lo que deterioraba el producto y encarecía su precio. Un estudio sobre la pesca en la costa de Aconcagua entre Maitencillo y Los Vilos, hacia 1900, señalaba que se podía comprar una lienza de congrio colorado de 5 a 8 kilos cada una sin vísceras, a un precio equivalente a 60 centavos el kilo. Transportado por mula a los pueblos vecinos de La Ligua o Catapilco, el precio llegaba al doble, y podía llegar a duplicarse nuevamente en el mercado de Valparaíso ${ }^{108}$.

Al incremento del precio por efectos del transporte se suma el deterioro del producto. De acuerdo a un estudio en el Boletín de Bosques, Pesca y Caza, la facilidad de descomposición dependía de la cantidad de agua que contenía el pescado. Los de carne más compacta y de régimen alimenticio más uniforme, se conservaban mejor que los peces que habitan aguas estancadas y los fondos de arena y que llevan una alimentación omnívora. Pero el factor más decisivo en la velocidad de descomposición de los pescados era la más o menos inmediata evisceración de que hubiera sido objeto. Un experto declaraba que: "un congrio destripado inmediatamente después de recogido del mar puede durar en invierno y manteniéndolo a la sombra en lugar fresco hasta cinco días sin descomponerse; pero con tripas, mantenido en las mismas condiciones, se descompone al segundo día"109.

105 Luis Uribe, "The Fishing Industry in Chile", traducido de la Revista de Marina, y publicado en The Chilean Committee of the Buffalo Exposition, op. cit., 29.

106 Gustavo Verniory, Diez años en la Araucanía, Santiago, Ediciones de la Universidad de Chile, 1975,102 y 111 .

107 Roberto Páez Constenla, "Vida cotidiana, historia y alimentación en el Norte Chico de Chile: el recetario ovallino de Concepción Sieulanne (Siglo XIX)", en Actas Americanas 11, La Serena, 2003, 20.

108 Wolnitzky, op. cit., 53-57.

109 Castillo, "Conducción del pescado", op. cit., 484. 
A comienzos del siglo XIX el pescado llegaba a Santiago desde los lugares de la costa más cercanos. Según el P. José Javier Guzmán, citado por Pereira Salas, el mercado al pie del puente de Cal y Canto recibía congrios de Valparaíso, corvinas de Concón, lisas de Santo Domingo, roncadores de Vichuquén, viejas de Puchuncaví, pichiguenes de Coquimbo, pejerreyes de Aculeo, choros de la isla Quiriquina, locos y picos de Coquimbo, ostiones y camarones de La Herradura y tacas del Huasco. Esta información parece discutible, salvo que se tratara de pescados y mariscos $\operatorname{secos}^{110}$. A mediados del siglo XIX, antes de la construcción del ferrocarril de Valparaíso, la capital se abastecía principalmente desde San Antonio, cuya pesca demoraba un día en llegar al mercado. James Gillis, que proporciona esta noticia, agrega que el pescado llegaba en mejor estado en el verano que en el invierno, lo que atribuía al efecto nocivo de la humedad ${ }^{111}$.

Vistas las distancias recorridas y los medios de transporte, la frescura de los productos dejaba que desear. Exagerando un poco las tintas, en 1874 un autor declaraba que los pescados que llegaban a Santiago eran "mortecinos, muertos asfixiados, no han desangrado, están con el germen de la putrefacción en sus carnes, como lo demuestra el olor de su descomposición" 112 .

La conclusión del ferrocarril hasta Talcahuano hizo que este puerto pasara a ser la principal fuente de suministro de la capital. Un informe oficial recogido en 1900 por Luis Delfín señala que los despachos por esta vía alcanzaban a 346 mil kilos anuales, de los cuales 200 mil correspondían a pescado y el resto a mariscos ${ }^{113}$. Años más tarde, la Dirección de Pesca y Caza proponía emplear vaporcitos para la pronta traída del pescado desde las caletas hasta los puertos principales, para su oportuna distribución por ferrocarril ${ }^{114}$.

Para asegurar mejor la frescura del pescado, en 1902 Luis Guglielmini, un empresario ligado al sector pesquero, envió por tren un cargamento de congrios, lisas y corvinas vivas desde Talcahuano a Santiago. Para ello utilizó depósitos de agua de mar instalados en el vagón ferroviario, cuyo contenido luego era vertido en unos estanques en la estación Alameda ${ }^{115}$. No conocemos el resultado de la experiencia. Más atinada nos parece una propuesta de la citada Dirección para asegurar la frescura del pescado, a saber, el empleo del frío para su conservación durante el transporte y comercialización: en 1912 solo existía un depósito refrigerado para estos fines en el país, pero a comienzos del año siguiente se anunciaba la próxima puesta en servicio de cuatro vagones frigoríficos en el ferrocarril longitudinal sur, lo que hizo pensar a dicho organismo que esto traería una baja en los precios de venta en Santiago ${ }^{116}$.

110 Pereira Salas, op. cit., 78-79.

111 J. M. Gillis, The U.S. Naval Astronomical Expedition to the Southern Hemisphere, Philadelphia, J. B. Lippincot, 1856, I, 49.

112 "La carpa", en BSNA V:19, julio de 1874, 406-407.

113 Fedrico Delfín, "The corvina of Chile", en The Chilean Committee of the Buffalo Exposition, op. cit., 43 .

114 Castillo, "Conducción del pescado", op. cit., 485-489.

115 Luis Salvo González et al., Historia de la Industria pesquera en la Región del Bio Bio, Santiago, ASIPES, 2000, 81; Sociedad Nacional de Pesquería, op cit., 41.

116 Luis Castillo, "Refrijeración y conjelación del pescado", en BBPC I:5, noviembre de 1912, $327-$ 334; "El Ferrocarril Longitudinal y el abaratamiento del pescado, en BBPC I:8, febrero de 1913, 506-507. 
Al amparo de este discurso público para el fomento de la pesca, se organizaron algunas sociedades anónimas con este objeto a comienzos del siglo XX. Dos de ellas fueron la Sociedad Aconcagüina de Pesquería y Conservas de Peces y Mariscos, creada en 1902, y la Sociedad Nacional de Pesquería, formada en $1904^{117}$. La base de sus negocios era precisamente la diferencia entre el costo del producto en la costa y su precio en los centros consumidores. Un estudio elaborado por los promotores de esta última, compara el valor de diversos pescados en Talcahuano, Quintero y otros puertos, y los precios mayoristas en Santiago. Tomando en cuenta la incidencia del flete y los márgenes de comercialización, el negocio no parecía demasiado atractivo para algunas especies, por lo que el prospecto aclaraba que "se puede obtener por la tercera parte de su valor cualquiera clase de los peces enumerados en la costa del archipiélago de Chiloé"118. El plan de la Sociedad Aconcagüina exponía argumentos similares, aunque sus operaciones eran a escala mucho más modesta: trabajaría con diez chalupas pesqueras aperadas, establecidas entre Algarrobo y Valparaíso, una falúa y un equipo de buceo para la extracción de erizos y choros, cuya producción se vendería al por mayor en las recovas de Valparaíso o en un local de ventas que se había puesto en Santiago. En el caso de esta empresa, cabe notar que los medios a emplear no representaban mayor innovación, salvo el equipo de buceo ${ }^{119}$.

No obstante todas las buenas intenciones, los resultados de la Sociedad Nacional de Pesquería fueron desafortunados. Según Federico Albert, dicha empresa cometió el error de

"hacer pescar con su vapor al norte de Valparaíso, donde tenía menos campo de acción, error que fue aumentado enormemente al botar unos 200 cajones de pescado para no venderlos barato, ni preocuparse de fabricar bacalao seco, i por último disgustarse voluntariamente con la gente esperta que traía i convertir un vapor de pesca con red de tiro en un estanque flotante para el acarreo de langostas vivas" 120 .

Agrega Albert que las demás sociedades pesqueras organizadas en Chile, algunas de las cuales tuvieron un carácter meramente especulativo, corrieron una suerte similar $^{121}$. Al parecer, tampoco hubo nuevas tentativas, a juzgar por la lista de sociedades anónimas cotizadas en bolsa en 1923, en que las sociedades pesqueras, aunque no las balleneras, brillan por su ausencia ${ }^{122}$. El reproche a las sociedades de pesca de alta mar lo repite Luis Castillo, quien postulaba que, ofuscados por "los espléndidos resultados [...], para no hacer bajar el elevado precio del pescado fresco han malogrado el exceso de la producción obtenida"123. Esta última crítica hace pensar que el problema no radicaba tanto en una supuesta codicia de los

117 Estatutos de la sociedad aconcagüina de pesquería y conserva de peces y mariscos, Valparaíso, Imprenta El Progreso, 1903; Sociedad Nacional de Pesquería, op. cit., 25.

118 Sociedad Nacional de Pesquería, op cit., 30-31.

119 Estatutos de la Sociedad Aconcagüina de Pesquería..., op. cit., 26-34.

120 Albert, El problema pesquero..., op. cit., 118-119.

121 Ibid., 119.

122 Julio Undurraga Ovalle, La riqueza mobiliaria de Chile..., Santiago, Sociedad Imprenta y Litografía Universo, 1923.

123 Luis Castillo, "La importación de pescado seco", en BBPC I:6, diciembre de 1912, 423. 
empresarios, cuanto en la caída de los precios por la mayor oferta, junto a la falta de un sistema de distribución y la persistencia de los hábitos de consumo.

No hemos encontrado datos medianamente confiables sobre el volumen de la pesca antes de 1900. La Estadística Comercial de la República de Chile registra el valor de las internaciones de la pesca en las diferentes aduanas de la República entre 1859 y 1922, sin precisar a qué corresponden exactamente. Más allá de ignorar el producto de la pesca artesanal, parecen manifiestamente incompletas y la caída de los valores registrados en los años anteriores a la descontinuación de la serie da la idea de un desinterés por recopilar datos que no guardaban relación con la realidad. En todo caso, el aumento que se aprecia en torno a 1900 es congruente con las iniciativas que tuvieron lugar por entonces y con los antecedentes que indicamos más abajo.

\section{GRÁFICO N 1}

\section{VALOR ANUAL DE LA PESCA SEGÚN LA ESTADÍSTICA COMERCIAL, $1859-1918$}

Promedio anual por quinquenios, en miles de pesos de $2007^{124}$

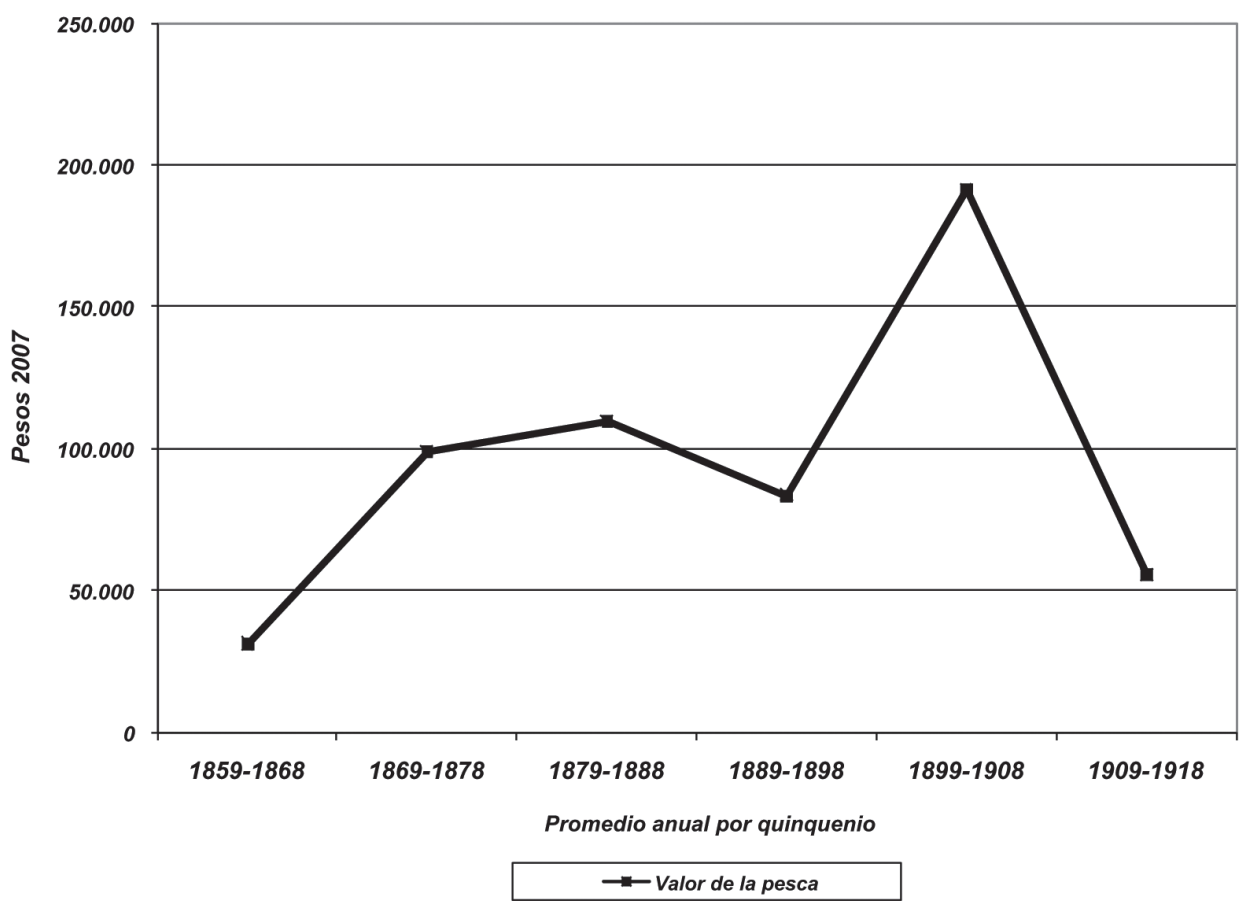

124 Estadística Comercial de la República de Chile, Valparaíso, varias imprentas, 1882-1922. Las cifras faltantes han sido interpoladas. 
Hay, empero, otras formas de aproximarse al tema. Si tomamos los datos de la productividad de los pescadores de San Antonio, citados por Uribe a partir de un informe de la Armada de 1897, y consideramos el número total de personas dedicadas a esta actividad, llegamos a una captura total de 2.259 toneladas, o sea menos de 840 gramos por habitante según el censo de $1895^{125}$. Esta cantidad nos parece excesivamente reducida. En todo caso, el número de pescadores en el país registrados en ese censo y su relación con la población total, indican que la actividad pesquera había llegado a un mínimo por entonces. En este sentido resulta significativo que la Matrícula de Patentes de Santiago para 1892 registre más de 250 pescaderías fuera de la recova, pero ninguna pescadería al exterior de la misma. Esta última situación fue cambiando con el local de la Sociedad Aconcaguina y la pescadería que para 1905 existía en calle San Antonio 454, dedicada de preferencia a la venta de ostras ${ }^{126}$. El número de pescadores repunta a partir de entonces, como se aprecia en el cuadro siguiente.

\section{CUADRO $\mathrm{N}^{\circ} 1$}

\section{NÚMERO DE PESCADORES POR CADA 10.000 HABITANTES 1875-1940, SEGÚN CENSOS INDICADOS ${ }^{127}$}

\begin{tabular}{lcccccc}
\hline Año & 1875 & 1885 & 1895 & 1907 & 1920 & 1940 \\
\hline Número total de pescadores & 1.542 & 1.570 & 1.637 & 3.833 & 4.502 & 4.688 \\
Pescadores por cada 10.000 habs. & 7,43 & 6,26 & 6,07 & 11,86 & 12,07 & 9,33 \\
\hline
\end{tabular}

Entre 1895 y 1907 hubo un fuerte aumento en el número de pescadores. El incremento es particularmente marcado en las provincias de Valparaíso y Concepción (Talcahuano) hasta 1920, lo que parece estar relacionado a los inicios de una modernización de la actividad y el consiguiente aumento de las capturas por pescador. En 1906 Federico Albert, en calidad de consultor técnico de una empresa pesquera en formación, estimaba el consumo de pescado y marisco en diferentes regiones, como sigue: en la Frontera, dos toneladas al día; en Talcahuano y Concepción, seis toneladas; en Talca, Linares, Curicó y Rancagua cuatro toneladas; en Santiago siete toneladas; en Valparaíso y Aconcagua, ocho toneladas; Tongoy, Coquimbo y La Serena, cuatro toneladas, lo que da un total de 31 toneladas diarias, es decir, 11 mil toneladas al año, sin contar el Norte Grande ${ }^{128}$. Esta cifra, que equivale a unos 3,8 kilos anuales por persona, resulta un tanto abultada, lo que

\footnotetext{
125 Uribe, op. cit., 31-32. Los cálculos del almirante arrojan una cifra inferior porque considera un número menor de pescadores que los indicados en el censo de 1895 .

126 El Mercurio, Santiago, 3 de junio de 1905, 2.

127 Los datos están tomados de los censos respectivos. No se ha considerado el efecto de un conteo inferior a la población real, porque esto habría afectado tanto a los pescadores como al total de personas. No se consideró el censo de 1930 porque los datos están incompletos.

128 Prospecto de la Compañía de Pesca Marítima, Santiago, Imprenta Cervantes, 1906.
} 
puede explicarse por el interés de presentar con mejores luces el negocio. Otra fuente, de 1920, señala que el consumo de pescados y mariscos frescos alcanzaba a 8.000 toneladas anuales, lo que daba un promedio de 2,25 kilos por habitante al año. En el caso de Santiago, el consumo se elevaba a 2,7 kilos al año por perso$\mathrm{na}^{129}$. Otros antecedentes indican que la provisión de pescados y mariscos fue creciendo en los años siguientes, si bien se estimaba que era muy baja para un país marítimo y muy inferior al consumo de carne. Jorge Mardones y Ricardo Cox, en su estudio sobre la alimentación en Chile, señalan que las capturas totales de peces entre 1930 y 1937, en cifras redondas, fueron las siguientes:

\section{CUADRO $\mathrm{N}^{\circ} 2$}

PRODUCCIÓN ANUAL DE PESCA 1930-1937

(toneladas) ${ }^{130}$

\begin{tabular}{lc}
\hline Año & Producción anual toneladas \\
\hline 1930 & 14.000 \\
1931 & 12.000 \\
1932 & 15.000 \\
1933 & 19.000 \\
1934 & 18.000 \\
1935 & 21.000 \\
1936 & 28.000 \\
1937 & 29.000 \\
\hline
\end{tabular}

Esta misma fuente consigna que, en 1935, el consumo de pescado en Chile fue de 5,28 kilos por habitante al año. Estas cifras son congruentes con las de Dragoni y Burnet recogidas por Salvador Allende, según el cual el consumo promedio entre 1928 y 1937 era de 5,9 kilos por habitante al año, contra 33,9 kilos de carne. El consumo de pescado era similar a Italia, pero inferior al de Francia, con 8 kilos, Alemania con 9, Inglaterra con 18 y Japón con 33 kilos. En cuanto a los mariscos, el consumo alcanzaba a 1,7 kilos al año ${ }^{131}$.

\section{LA CONSERVACIÓN DEL PESCADO}

La forma tradicional de conservar el pescado era prepararlo seco o salado. La elaboración de pescado seco en Chile era de antigua data, no así el salado, cuyas técnicas fueron desconocidas hasta fines del siglo XIX. Comentando sobre la pesca

129 "La industria de la pesca en Chile", en BSFF XXXVII: 8, agosto de 1920, 459-461.

130 Jorge Mardones R. y Ricardo Cox B., La alimentación en Chile. Estudios del Consejo Nacional de Alimentación, Santiago, Imprenta Universitaria, 1942, 89.

131 Mardones y Cox, op. cit., 91; Salvador Allende, La Realidad Médico-Social Chilena (Síntesis), Santiago, Ministerio de Salubridad, Previsión y Asistencia Social, 1939, 41-46. 
en la bahía de Penco a comienzos de esa centuria, el coronel Juan de Ojeda criticaba sus métodos rudimentarios y agregaba: "no saben salar ni sazonar el pescado, insípidamente lo secan, reduciendo este delicado manjar al más áspero, insulso y grosero comestible, que no admite sazón alguna"132.

Este comentario podría ser aplicado a otras regiones. Los changos en Atacama se dedicaban al secado del congrio, parte del cual se transportaba a Coquimbo y al resto del país. Por entonces, se vendía en dicho puerto a 16 y 18 pesos el quintal, mientras que en el resto del país iba, por lo general, de 24 a 30 pesos $^{133}$. El precio fue en descenso: Rodulfo A. Philippi, en su visita a la zona en los años 1850 , informa que el pescado seco de Atacama se entregaba a los almacenes locales, donde se le pagaba a razón de dos pesos la arroba, es decir, alrededor de 7,80 el quintal ${ }^{134}$. Aun así, estos valores resultan bastante más elevados que los que figuran en la tarifa de avalúos de 1823 , donde el pescado seco nacional se tasaba a 5 pesos el quintal ${ }^{135}$.

Pomar, escribiendo a fines del siglo, se refiere al secado de la sierra en Chiloé mediante hornos ${ }^{136}$. Agrega que, durante un tiempo, también se secaba el róbalo para su envío al norte, pero que el producto era tan malo que el consumo no alcanzó niveles remunerativos, y fue suplantado por el pescado extranjero o de la costa chilena más cercana ${ }^{137}$. De los mariscos del archipiélago, los choros zapato de Chiloé se secaban para su envío al norte y exportación al extranjero. Las tacas y los piures se secaban mediante un curanto. Las primeras eran luego desgranadas y enlatadas, o si no eran ensartadas en un coirón, y luego ahumadas antes de ser vendidas en Castro ${ }^{138}$.

Como vemos, el pescado nacional seco o ahumado encontraba mercado en el país, pero tenía un problema de calidad. De ahí el artículo en el Boletín de la Dirección de Bosques Pesca y Caza, que entregaba instrucciones para elaborar pescado seco, proceso que incluía una inmersión en salmuera y su exposición al sol. Los peces chilenos más apropiados para secar eran, a su juicio, el congrio, la corvina, el lenguado y la pescada. Este último era el pescado que se secaba con mayor prontitud y el que mejor se descoloraba con la acción del sol, aunque, al igual que el congrio, perdía la mitad de su peso durante la operación ${ }^{139}$.

En esta misma línea, la ya mencionada Sociedad Nacional de Pesquería proyectó capturar bacalao en Juan Fernández y prepararlo seco a la manera de los norue-

132 Juan de Ojeda, "Informe descriptivo de la frontera de la Concepción de Chile" [1803], en Nicolás Anrique, Biblioteca Geográfico-Hidrográfica de Chile, Santiago, Imprenta Elzeviriana, 1898, 275, citado por Salvo et al., op. cit., 31 .

133 "Informe de la Expedición Malaspina”, s.a., s.f., en Rafael Sagredo y José Ignacio González, La Expedición Malaspina en la frontera austral del Imperio español, Santiago, Centro de Investigaciones Diego Barros Arana, Editorial Universitaria, 2004, 681.

134 Philippi, Viaje al desierto..., op . cit., 28.

135 Avalúo de efectos extrangeros, Santiago, Imprenta el Gobierno [1823], 8.

136 Pomar, op. cit., 17.

137 Pomar, op . cit., 15, y 21

138 Pomar, op. cit., 22-23, 27 y 40-41; Maldonado, op. cit., 173.

139 Luis Castillo, "El medio más económico de secar el pescado", en BBPC I:3, septiembre de 1912, 196-199. 
gos, así como ahumar anguilas, presumiblemente con métodos modernos, para venderlas en el continente ${ }^{140}$. Más tarde, en 1918, Bernardo Alexandrovich Jerson, judío-ruso de una familia de tradición pesquera, estableció en Talcahuano el saladero Pacífico, cuyos productos encontraron buen mercado en el casino de Viña del Mar, las termas de Chillán y especialmente entre la colonia judía de Santiago ${ }^{141}$.

La fabricación de pescado seco o salado no tenía, empero, un gran futuro. Como observaba Luis Castillo, su producción estaba limitada tanto por el precio de la materia prima como por la competencia del pescado fresco desde aquellos lugares conectados por ferrocarril a los centros de consumo ${ }^{142}$. El producto fresco era preferido por el público si estaba disponible. Como escribe William Howard Russell a propósito de Iquique, "el mar proporcionaba [...] corvinas, congrios y lisas, y cuando no lo hacía, siempre se podía recurrir (pero no para mí) al bacalao salado" 143 .

En cuanto a la conserva de pescados y mariscos en envases de hojalata, sus inicios se remontan a mediados del siglo XIX. Por lo que sabemos, la primera iniciativa corresponde a Francisco Sciaccaluga, que estableció una fábrica en Talcahuano dedicada a envasar choros y otros mariscos en $1864^{144}$. En 1869 este industrial presentó unos choros en conserva en la exposición de agricultura efectuada ese año en Santiago, y más tarde se instaló en Calbuco, donde aparece operando en forma sostenida a partir de $1880^{145}$. Las condiciones naturales de esa zona dieron origen a nuevas industrias conserveras de mariscos en los años siguientes. En la última década del siglo XIX se comenzó a enlatar el róbalo y el pejerrey en Chiloé, pero en cantidades muy pequeñas, por lo incierto del mercado consumidor; también se preparaban allí conservas de erizos con aquellos de mejor calidad $^{146}$. Un anuncio de D. Spencer y Cía. de Valparaíso de 1884 ofrecía “conservas chilenas" de choros, choritos, micos, ostras, tacas, caracoles y navajuelas, además de erizos, centollas, róbalo, pejerreyes y otros productos de tierra ${ }^{147}$. También había ostras en conserva, como las que ofrecía el almacén de abarrotes de Pedro Ordorica y Cía. en 1872, aunque probablemente estas eran importadas ${ }^{148}$.

En 1887 se formó en el estero de Huito, vecino a Calbuco, la fábrica de conservas El Cometa, de Emile-Auguste y Laurencia de Solminihac, que envasaba pescados y mariscos, los que eran distribuidos en Santiago por la Agencia de Industrias

140 Sociedad Nacional de Pesquería. op. cit., 25.

141 Salvo et al., op. cit., 81.

142 Castillo, "El medio más económico de secar", op. cit., 199.

143 Cf. Russell, op. cit., 141.

144 Sergio Ceppi et al., Chile 100 años de industria 1883-1983, Santiago, Sociedad de Fomento Fabril, 1983, 275.

145 Catálogo oficial de la exposición de Agricultura inaugurada solemnemente en Santiago el 5 de mayo de 1869, Valparaíso, Imprenta del Mercurio, 1869, 185; Ceppi et al., op. cit., 275; Esteban Barruel y Floridor Cárdenas, Historia cotidiana y contemporánea del pueblo de Calbuco en el siglo $X X$, Santiago, Salesianos, 2002, 15-16.

146 Pomar, op. cit., 15, 21, 27.

147 Almanaque comercial para el año de 1884, Valparaíso, Imprenta de la Patria, 1883, 41.

148 Almanaque pintoresco para el año bisiesto de 1872, Santiago, Imprenta de la Librería del Mercurio, 1871. 
Nacionales de Felipe Tupper ${ }^{149}$. Una muestra de estas conservas, incluyendo centolla, además de gallinas y extracto de carne, fue exhibida en la exposición industrial de Santiago de 1894. Los productos, presentados bajo la marca La Gaviota, recibieron el primer premio por su variedad ${ }^{150}$. Más tarde se crearon en Calbuco otras conserveras de mariscos y otros alimentos, como las de Jorge Segundo Ditzel y Carlos Oelkers, ambos llegados de Puerto Montt y establecidos en 1909, y la Estrella del Sur, de Luis Alfredo de la Puente, que ya funcionaba en 1910. Las conservas de Ditzel eran de gran calidad: habiendo obtenido premios en la Exposición Nacional de Industrias de Santiago en 1910, en la Exposición Industrial de 1916 y en la Exposición de Sevilla de $1929^{151}$.

En 1901 el italiano José Chibbaro se instaló en Talcahuano con una industria de pescado en conserva y seco, cuyos productos "no tenían nada que envidiar a sus similares importados”, pero que resultó de corta vida. En 1908 los hermanos Solá Armas, naturales de Galicia, establecieron una planta para conservas de pescado en la bahía de San Vicente, donde elaboraban sardinas en aceite y salsa de tomates, filetes de anchoas, sierra tipo salmón y "salmón" en aceite y champiñones. Los pescados eran comprados a los pescadores artesanales de la región y toda su producción se vendía en el país ${ }^{152}$. Más pequeña era la industria de A. Winter y Cía., de Puerto Saavedra, que en 1914 enlataba corvina, lisa y machas al natural ${ }^{153}$.

La demanda por la langosta dio origen a una temprana industria conservera en Juan Fernández. Esta fue iniciada por Alfredo de Rodt, quien en 1892 se relacionó con la firma de Carlos Fonck y Cía. de Valparaíso, interesada en instalar una fábrica de conservas de langosta en la isla. La fábrica entró a funcionar al año siguiente y sus productos fueron expuestos en la exhibición de la Sociedad de Fomento Fabril de 1894, donde obtuvo un primer premio. La firma Fonck \& Cía. también enlataba el bacalao de Juan Fernández en pequeñas cantidades. Para 1901 ya había tres conserveras en la isla, a las que se debía sumar la fábrica de la Sociedad Nacional de Pesquería. Esta última proyectaba envasar además la vidriola, susceptible de venderse en conserva como sucedánea del salmón ${ }^{154}$. Entre 1894 y 1899 la fábrica de Fonck produjo un promedio 40 mil tarros al año, lo que habría representado una captura de casi 20 mil ejemplares anuales. Digamos, de paso, que los cálculos de la Sociedad de Pesquería al respecto eran levemente

149 Ceppi et al., op. cit., 279; Hernán de Solminihac Andrade y Carlos Bórquez Carlini, La familia de Solminihac. Estudio genealógico e histórico 1192-1995, Santiago, Talleres Gráficos del Instituto Nacional de Pastoral Rural, 1996, 246-250 y 258.

150 "Catálogo de la exhibición de productos industriales organizada por la Sociedad de Fomento Fabril", en BSFF XI, 1894, 402-448.

151 Barruel y Cárdenas, op. cit., 16-17 y 78.

152 Salvo et al., op. cit., 79-80.

153 "Miscelánea", en BBPC II:12, junio de 1914, 605

154 Max Ruh, “Alfredo de Rodt. Subdelegado en Juan Fernández 1877-1905”, en Mario Orellana et al., Las Islas de Juan Fernández. Historia, arqueología y antropología de la Isla Robinson Crusoe, Santiago, Departamento de Ciencias Antropológicas y Arqueológicas, U. de Chile, 1975, 115-116; "Catálogo de la exhibición...", op. cit., 403 y 449-450; Sociedad Nacional de Pesquería, op. cit., 24-25. 
distintos: una langosta permitía llenar solo $1 / 2$ a $1 / 4$ de estos tarros de una libra $(460 \text { gramos })^{155}$.

En todo caso, y pese a estas iniciativas, la industria de conservas de pescados y mariscos en Chile era de poca envergadura. En 1914 solo existían seis fábricas en todo el territorio, con una venta anual de $\$ 1.050 .543$ y cuyo capital total alcanzaba a 948 mil pesos, lo que se compara con las 24 conserveras de frutas y legumbres, con un capital total nueve veces mayor ${ }^{156}$.

\section{LA PISCICULTURA}

Frente al problema de la conservación y el agotamiento de los recursos de mayor demanda, la piscicultura parecía ofrecer una solución. Con todo, la introducción de peces comestibles de agua dulce a Chile durante el siglo XIX no resultó exitosa. El cultivo más promisorio era el de la carpa, un pez "muy estimado en Europa por su sabrosa carne y muy apropiado para vivir en estanques y pequeños lagos", según Rodulfo A. Philippi ${ }^{157}$. Un artículo en el Boletín de la Sociedad Nacional de Agricultura, de comienzos de 1874, daba cuenta de la llegada de una partida de carpas vivas destinadas a la reproducción y que habían sido encargadas por el doctor Carlos Segeth. El autor destacaba la facilidad con que se multiplicaban y la rapidez con que aumentaban de peso: después de cuatro años una carpa de 60 gramos llegaba a pesar un kilo. Hacía ver que, por el hecho de poder venderse vivas, transportándolas en jabas de madera inmersas en agua, la carpa tenía mejor sabor que los pescados que se consumían habitualmente, y estimaba que su producción resultaba un buen negocio ${ }^{158}$.

Pocos meses más tarde, el Boletín volvía sobre el tema, promoviendo las virtudes de la carpa. Se la comparaba con la gallina y la oveja, "por haberse prestado perfectamente a la domesticidad". Para su cultivo -explicaba- se requerían estanques de 1,50 a 2 metros de profundidad, cuyo fondo sea provisto de una hierba de hoja menuda, como la llamada hierba del Pato, que estén rodeadas de sauces para darle sombra y "que cuenten con un hilito de agua para reponer la que diariamente se evapora". Las carpas se multiplicaban con rapidez y estimaba que se podrían vender fácilmente a 10 centavos la libra (460 gramos). Más interesante era la posibilidad de llevarlas vivas a la recova, transportándolas en barriles; esto permitiría al comprador comer pescado fresco o aun conservarlo vivo en su casa, y al vendedor llevar de vuelta al criadero lo que no hubiera colocado. Con todo, reco-

155 Ruh, op cit., 116; Sociedad Nacional de Pesquería, op. cit., 23-24; según Albert (La langosta..., op. cit., 8.), la producción hacia 1900 era entre 2.500 y 4.000 cajas de conservas de nueve libras neto, pero el número de langostas capturadas que indica no guarda relación con lo anterior; Castillo, "Conducción del pescado...", op. cit., 487.

156 Oficina Central de Estadística, Chile económico, 1914, Santiago, Soc. Imprenta y Litografía Universo, 1914, 51.

157 Rodulfo Amando Philippi, "Sobre los animales introducidos en Chile desde su conquista por los españoles", en Anales de la Universidad de Chile LXVIII, Santiago 1885, 326.

158 "La piscicultura", en BSNA V:7, 20-1-1874, 145-147. 
nocía que la partida de carpas traída a Chile a comienzos del año no había generado demasiado interés, pese a los términos lucrativos en que presentaba el negocio $^{159}$. Philippi menciona esta y otra iniciativa por cultivar la carpa, pero agrega que los ejemplares no se multiplicaron ${ }^{160}$. Una explicación la ofrecía Nathan Miers Cox, al observar la mala experiencia en la Quinta Normal de Agricultura, que atribuía a la falta de alimento apropiado, al punto que las carpas se habrían comido sus propios huevos ${ }^{161}$. Según otra fuente, se logró afianzar el cultivo de la carpa, pero los ejemplares estaban muy degenerados y, hacia 1914, Federico Albert introdujo una nueva partida de las mismas ${ }^{162}$.

Igualmente negativos fueron los resultados para introducir el salmón en las aguas chilenas. Philippi se refiere al intento de José Tomás Urmeneta, quien hizo venir huevos de esta especie en recipientes debidamente refrigerados y acondicionados. Sin embargo, y por razones imprevistas, los huevos quedaron 70 días en el contenedor, y cuando él los abrió por encargo de Urmeneta, la mayoría de ellos estaban muertos o cubiertos de moho ${ }^{163}$.

Guillermo Lawrence, escribiendo en el Boletín de la Sociedad Nacional de Agricultura, en 1874, cuenta que había logrado interesar a Luis Cousiño en la introducción de salmones en el sur, pero que este falleció antes de llevar a cabo la iniciativa. Lawrence pensaba que bastaba encargar a los cónsules chilenos en Inglaterra y Francia que remitieran una cantidad de ovas por un vapor, por la vía del Estrecho hasta Coronel, tal como se habían enviado a Australia con buen logro. Aunque el experimento no tuviera éxito y hubiera que repetirlo varias veces, estimaba que su "costo sería siempre insignificante comparado con el gran beneficio que al fin reportaría [...] Su carne sabrosa y alimenticia es a la vez bocado apetecido por los ricos y de un valor inapreciable para los pobres y su introducción sería para el país en general la de un nuevo y muy sano alimento"164.

La viuda de Cousiño, doña Isidora Goyenechea -dice Philippi-, mandó traer ovas de salmón junto con un técnico escocés encargado de su cultivo. Estas fueron sembradas en el arroyo de Chivilingo, cerca de Lota, pero, al poco tiempo, grandes aguaceros aumentaron su caudal, el cual se llevó toda la cría de peces al mar ${ }^{165}$. Doña Isidora había solicitado privilegio exclusivo para la crianza de salmones, pero la solicitud fue rechazada, quizás porque estaban en marcha otros intentos. En todo caso, el Gobierno tenía interés en su cultivo y se asignó la suma de $10 \mathrm{mil}$ pesos, "para procurarse instructores de la cría de salmón y los elementos necesarios para ello"166. En agosto de 1885 el Gobierno informó a la Sociedad Nacional

\footnotetext{
159 "La carpa", op. cit.

160 Philippi, "Sobre los animales...", op . cit., 326.

161 Nathan Miers-Cox, "Piscicultura. La crianza de la carpa", en BSNA XVII:18, julio de 1886,

162 Virgilio Figueroa, Diccionario Histórico y Biográfico de Chile, Nendeln, Lichtenstein, Kraus Reprint, 1974, tomo I, 270.

163 Philippi, "Sobre los animales...", op. cit., 326.

164 Guillermo Lawrence, "Introducción del salmón en los ríos de Chile", en BSNA V:10, marzo de 1874, 206-208. El artículo está fechado en Concepción a 28 de enero de 1874.

165 Philippi, "Sobre los animales...", op. cit., 326.

166 Nathan Miers Cox, "No 10 sobre piscicultura", en BSNA XVI:13, 20 de abril de 1885, 261-262.
} 395-396. 
de Agricultura que el cónsul chileno en San Francisco de California había enviado un técnico con ovas de salmón para ser introducidas en los ríos de Chile, y encargó a dicho organismo adoptar las medidas necesarias para su desarrollo en la Quinta Normal ${ }^{167}$. La Sociedad Nacional de Agricultura logró mantener vivos algunos ejemplares, de los cuales envió una muestra a la exposición de piscicultura efectuada en Londres en $1883^{168}$.

En 1886 el Gobierno consiguió nuevamente del Congreso la suma de 10 mil pesos para la introducción del salmón y otros peces en los ríos de Chile. Las gestiones fueron encargadas a Julio Besnard, quien visitó establecimientos de piscicultura en Londres, en la Saboya francesa, en Suiza y el del Trocadero de París. En este último encontró los elementos requeridos. Gracias a las gestiones del ministro de Chile en Francia, obtuvo facilidades de la alcaldía de la ciudad para adquirir tres estanques metálicos y un surtido de peces vivos -100 salmones de California, 40 carpas, 20 tencas 20 barbos, 20 orfes y 60 anguilas, los que fueron despachados de inmediato, a la vez que encargó el envío posterior de ovas de las mismas especies. Los estanques y los peces llegaron en buenas condiciones a la Quinta Normal, pero las ovas, que eran la base de la reproducción, se perdieron en el viaje ${ }^{169}$.

Los intentos oficiales no cejaron. Federico Albert, a la cabeza de la Dirección de Bosques, Pesca y Caza, instaló una piscicultura en el río Blanco hacia 1912 y trajo partidas de ovas de salmón del Rin, salmón acerado, trucha salmonada y de otras variedades, las que, gracias a sus cuidados, llegaron en buenas condiciones. Las distintas especies fueron distribuidas en los ríos chilenos entre el Aconcagua y el Petrohué. No todas las especies se dieron igualmente bien en todas las regiones; además de los problemas de adaptación, se debió hacer frente a la acción de pescadores furtivos, la pesca con dinamita y las depredaciones del pez dorado y otra fauna que se alimentaba de los salmones cuando estos bajaban al mar, pero la citada Dirección confiaba en la propagación de estas especies ${ }^{170}$. Algo se avanzó: en 1913 dicho organismo informaba que los salmones prosperaban en las aguas del sur, con ejemplares que alcanzaban los 50 centímetros ${ }^{171}$.

La Dirección de Pesca y Caza siguió promoviendo la piscicultura. Un artículo aparecido a fines de aquel año, informaba sobre "los peces más convenientes para el cultivo artificial en el país"; estos incluían no solo distintas variedades foráneas de salmón, trucha y carpa, sino también la trucha del país y los pejerreyes ${ }^{172}$.

167 "Ramón Barros Luco a Sociedad Nacional de Agricultura", 3 de agosto de 1885, en BSNA XVI:22, 5 de septiembre de $1885,474$.

168 "Memoria de los trabajos ejecutados por el Directorio [de la Sociedad Nacional de Agricultura]...”, en $B S N A X V: 1,20$ de octubre de 1883,1-5.

169 "Piscicultura", en BSNA XVIII:1, 20 de octubre de 1886, 1; "Piscicultura: introducción del salmón, carpas y anguilas vivos", en BSNA XVIII:3, 20 de noviembre de 1886, 80-83. Se reproduce la carta de Besnard al ministro del Interior del 2 de noviembre de 1886; "Crónica agrícola. Piscicultura", en BSNA XVIII:13, 20 de abril de 1887, 385; "Crónica agrícola. Peces para la Quinta Normal”, en BSNA XVIII:14, 5 de mayo de $1887,427$.

170 Sage, op . cit., 299-307. Cf. Figueroa, op. cit., I, 269-270.

171 "Salmones en el sur", en BBPC I:12, mayo de 1913, 789-790.

172 Pedro Golusda, "Descripción de los peces más convenientes para el cultivo artificial en el país”, en BBPC II:6, diciembre de 1913, 348-367. 
En el caso de las ostras, la temprana sobreexplotación del recurso ya mencionada, elevó los precios y llevó al desarrollo de criaderos de este y otros moluscos. Weber se quejaba de que, cuarenta años antes, el ciento de ostras escogidas costaba cinco centavos, mientras que ahora, "la ostra ha llegado a ser un artículo de lujo en Chile". Y agrega: "hoy, el comercio está monopolizado por uno o dos franceses de Ancud que tienen sus depósitos y contratos con el norte. A veces es más fácil comprar ostras en Santiago que en Ancud"173. Los franceses aludidos eran Emilio y Laurencia de Solminihac, que establecieron el primer criadero de ostras en el estero de Huito, departamento de Carelmapu. Los De Solminihac eran bretones y sabían sobre el cultivo de la ostra. Arribaron a Chile en 1887 y anunciaron a la Sociedad Nacional de Agricultura su propósito de dedicarse a esta tarea, que implicaba una tecnología bastante nueva, pues hacía solo 20 a 25 años que se había introducido su crianza en Francia. Para el cultivo hacían recoger las semillas de ostras en los bancos naturales de Quetalmahue en Ancud, las que de otro modo iban a morir en las playas o ser comidas por los peces, y cuando alcanzaban cierto tamaño, eran llevadas al criadero Calbuco. El criadero, que tomó el nombre de Francos-Chilenos [sic], terminó en manos de doña Laurencia y su hijo. Las ostras se demoraban 15 días en llegar desde el criadero a Santiago. Eran embarcadas a Valparaíso y de ahí seguían por tren a la capital. Para mantener las ostras frescas, se colocaban en barriles con un enjaretado de quila, los que eran rellenados con agua de mar. Cuando llegó el ferrocarril a Puerto Montt el viaje se redujo a cinco días. Con el tiempo surgió la competencia pero, al decir de la familia, las "ostras Solminihac" conservaron una reputación por su calidad, presentación y limpieza ${ }^{174}$.

\section{LOS PESCADOS IMPORTADOS}

Las carencias de pesca nacional fueron suplidas con importaciones. La tarifa de avalúos para el año 1823, la primera que se conoce, solo registra el bacalao, se entiende seco o salado, que estaba tasado en 8 pesos por quintal de 46 kilos, y el salmón, sin tasación, presumiblemente porque su presencia en la plaza no era frecuente. Un anuncio de Martín González, de 1825, ofrecía bacalao de Terranova a 10 pesos por quintal, equivalente a poco más de 21 centavos el kilo. El producto venía en barricas de cinco arrobas ${ }^{175}$.

Para 1836 el bacalao había bajado a 5 pesos el quintal, es decir, 11 cts. el kilo, mientras el salmón aparece tasado al equivalente de 13 centavos. La tarifa de avalúos de 1846 registra además el congrio seco al mismo precio que el bacalao, y

173 Weber, “Apuntes sobre Chiloé”, op. cit., 432.

174 Nathan Miers Cox, "La ostra", en BSNA XVIII:16, junio de 1887, 506-509; De Solminihac y Bórquez, op. cit., 258-265; Maldonado, op. cit., 172. Solminihac recoge la descripción del criadero publicada por Aníbal Escobar en el Anuario de la Colonia Francesa en Chile, Santiago, Imprenta y Litografía La Ilustración, 1926.

175 El Avisador Chileno, $\mathrm{N}^{\circ}$ 17, 21 de enero de 1825, en Colección de Antiguos Periódicos Chilenos, tomo XIX, Santiago, Ediciones de la Biblioteca Nacional, 1966, 145. 
el salmón a 17 centavos el kilo. Hay que tener presente que ya en la década de 1860 el nombre "bacalao" pasó a ser genérico para el pescado seco, con excepción del que se importaba de Perú, China y Japón. Para efectos de aduana, otros peces grandes como el abadejo y el macrel eran tasados al mismo precio que el bacalao. Conforme se devaluaba la moneda, el valor aduanero del pescado aumentó; llegaba a 40 centavos el kilo para 1908, pagando entonces un derecho de 14 centavos, gravamen aumentado a 20 cts. en $1916^{176}$.

El Gráfico $\mathrm{N}^{\circ} 2$ muestra que las importaciones de pescado seco, tanto en términos absolutos como la cantidad por habitante, aumentaron en forma más o menos sostenida hasta la Primera Guerra Mundial.

\section{GRÁFICO N²}

\section{IMPORTACIÓN DE PESCADO SECO 1844-1930177}

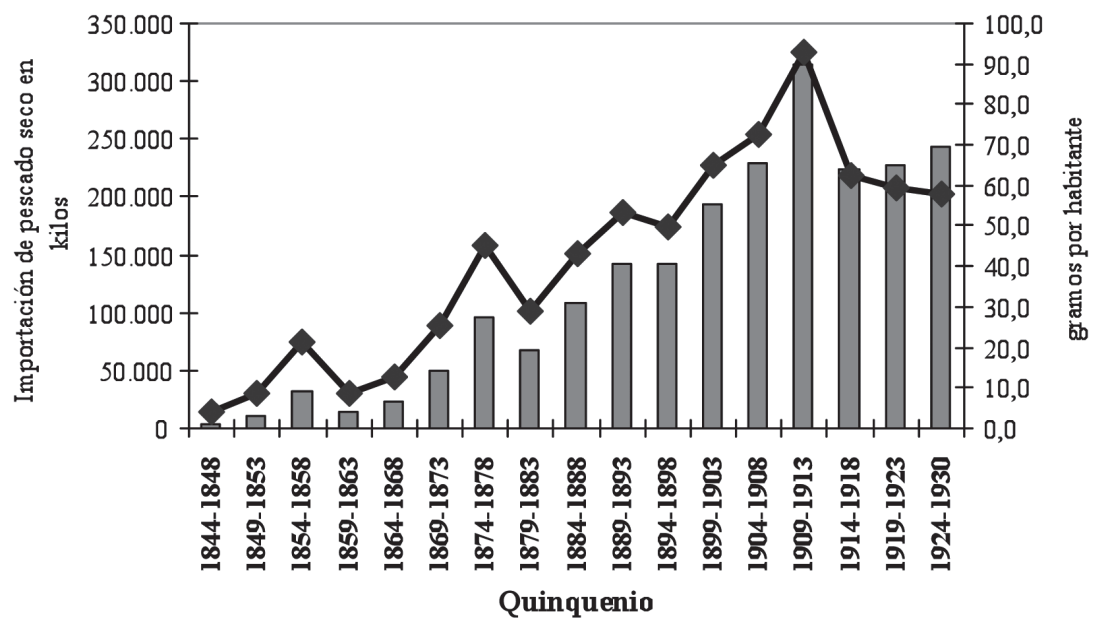

Importación en kilos promedio anual Gramos por habitante promedio anual

176 Avalúo de efectos extrangeros, op. cit., 2; Tarifa de Avalúos para las aduanas de la República... 1836], Valparaíso, Imprenta del Mercurio, [1837], s.p; Tarifas que deben regir en las aduanas de la República para el año de 1845, Valparaíso, Imprenta del Mercurio, 1844; Tarifa de avalúos que rije en las aduanas desde el $1^{\circ}$ de enero del año 1908, Valparaíso, Sociedad Imprenta y Litografía Universo, 1908; Ministerio de Hacienda, Arancel Aduanero, Ley número 3066 y decreto reglamentario (edición oficial), Santiago, Imprenta Nacional, 1916. A partir de 1898 los valores aduaneros se expresan en pesos de $18 \mathrm{~d}$.

177 Estadística Comercial de la República de Chile, op. cit., 1844-1915; Anuario estadístico de la República de Chile, Santiago, varias imprentas, 1916-1930. 
En el comercio se expendían dos clases de "bacalao", con espinas y sin espinas. En 1912, el primero se vendía al por menor entre \$1,50 y \$2,30 la libra según calidad, mientras que el segundo tenía un precio de un peso la libra. La explicación está en que el verdadero bacalao, "llamado vulgarmente bacalao de Noruega, de Escocia o de Terranova, es el primero, el que tiene espinas. Este producto es de muy diferente sabor que el otro, que el bacalao sin espina, y de consistencia más fibrosa". Este último correspondía al dorsch, o bacalao del Báltico de los alemanes y daneses, y al anon, o bacalao del Mar del Norte, y era el que llegaba con mayor frecuencia a Chile. En cuanto al pescado seco que llegaba del Mediterráneo, de China, Japón y del Pacífico sudamericano, era de diferentes especies, de las cuales la más corriente era la merluza ${ }^{178}$. El gráfico siguiente, que muestra la importación por países en años seleccionados, confirma el aserto anterior.

\section{GRÁFICO N 3}

\section{IMPORTACIÓN DE PESCADO SECO POR PAÍSES EN KILOS ANUALES, 1846-1926 \\ Años seleccionados 179}

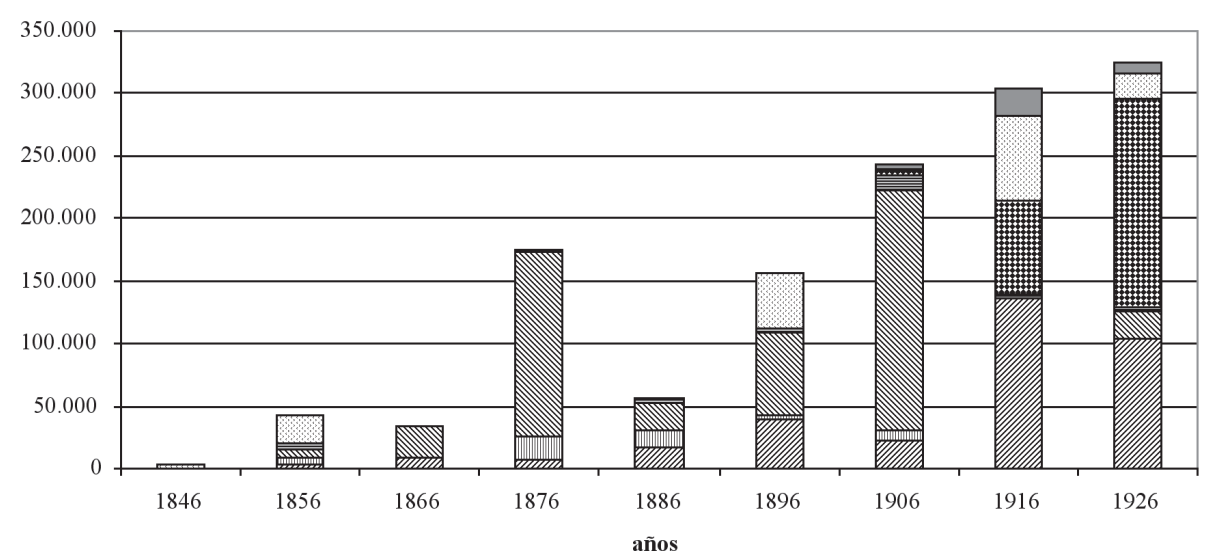

\begin{tabular}{|c|c|c|c|}
\hline Gran Bretaña & 四 Francia & $\mathbb{\mathbb { N }}$ Alemania & 目 Italia-España \\
\hline 㽗 Escandinavia & Estados Unidos & $\square$ Otros & \\
\hline
\end{tabular}

Un segundo rubro corresponde a pescados pequeños, como anchoas, sardinas y arenques, los que solían venir tanto secos como ahumados, sea en aceite o en salmuera. Estos podían ser importados a granel, y vendidos sueltos o envasados local-

178 Castillo, "La importación de pescado seco...", op. cit., 420.

179 Estadística Comercial de la República de Chile, op. cit., 1844-1915; Anuario estadístico de la República de Chile, op . cit., 1916-1930. 
mente, caso en el cual eran tasados a 22 centavos el kilo en 1863, mientras que el pescado que venía enlatado estaba avaluado a 87 centavos. El arancel de 1898 distinguía entre conservas de pescados y mariscos en aceite, tasadas a 60 centavos el kilo bruto, las conservas en salmuera, vinagre o salsas, a 50 centavos y los importados a granel, tasados a menor precio. La sardina era el pescado en conserva de mayor consumo; estaba avaluado en 60 centavos el kilo sin hacer distingo entre el producto en aceite, en salmuera o en salsas, las que podían incluir trufas.

En cuanto al arancel, en 1863, todos los pescados en conserva pagaban un derecho de internación de 25\%. Para 1898 este gravamen se había elevado a 60\%, una medida proteccionista para favorecer la industria nacional, aunque se hizo excepción de la sardina; esta siguió pagando el mismo impuesto anterior hasta 1908, cuando aumentó al 35 por ciento, posiblemente porque para entonces ya se envasaban en el país. La tarifa de avalúos de ese año, estableció una categoría especial para el salmón en lata, tasado a un precio inferior al de la sardina, 50 centavos el kilo, y que pagaba un arancel de solo 25 por ciento ${ }^{180}$. El menor impuesto a la sardina y al salmón indica que no se consideraban artículos de lujo, sino más bien un producto al alcance de los sectores medios y aún populares ${ }^{181}$.

Los anuncios publicitarios dan cuenta de la creciente variedad de conservas de pescados y mariscos disponibles por entonces. El almacén Las dos Californias, de Pedro Sanz y Cía. en Valparaíso, ofrecía "conservas surtidas de pescado" en escabeche y en aceite: calamares, sardinas, besugo, merluza, róbalo, robaliza, mero y anguilas, todas importadas directamente desde España ${ }^{182}$. También llegaban anchoas, atún, sardinas, langosta, bacalao y arenques, en aceite, agua o salmuera, como los que ofrecían el Almacén Romano, de Eduardo Ferrero, el de Pedro Ordorica y Cía., en Santiago, y el de Besa y Salinas de Valparaíso ${ }^{183}$. La lista de avalúos aduaneros también hace referencia a la importación de abadejo y "macrel" ya mencionados, así como de langosta, camarones, ostras y ostiones ${ }^{184}$.

Las importaciones de sardinas, individualizadas a partir de 1884, muestran un aumento sostenido hasta la Primera Guerra Mundial (gráficos oo 4 y 5).

180 Tarifas de Avalúos que con el arreglo al sistema métrico decimal deberán rejir en las aduanas de la República de Chile el $1^{\circ}$ de Enero del año de 1863, Valparaíso, Imprenta del Comercio, 1862; Tarifa de avalúos que rije en las aduanas de la república de Chile desde el $1^{\circ}$ de enero del año 1898 modificada con arreglo a la ley núm. 980 de 23 de diciembre de 1897, Valparaíso, Imprenta del Universo de Guillermo Helfmann, 1902; Tarifa de avalúos que rije en las aduanas desde el $1^{\circ}$ de enero del año 1908, op. cit.

181 Al respecto es indicativa la anécdota de Benito Salazar, chofer de auto, quien, estando en situación económica estrecha pudo darle algún dinero a su mujer para que comprara un tarro de salmón, pan, vino y cebolla, e hiciera un almuerzo. Benito Salazar Orellana, Memorias de un peóngañán, Gabriel Salazar V. (editor), Santiago, Lom Ediciones, 2008, 113.

182 Guía comercial de firmas, Valparaíso, Imprenta general y librería de Julio Real y Prado, 1884, 17.

183 Jacinto Núñez, Almanaque divertido para 1875, Santiago, Imprenta de la República, 1874, s.p; Román Vial, Almanaque Nacional para 1877, Valparaíso, Imprenta del Mercurio, 1876, 56; Almanaque nacional para 1877, Valparaíso, Imprenta del Mercurio, 1876, 38; Almanaque pintoresco para el año bisiesto de 1872, op. cit., s.p.

184 Ver Tarifa de avalúos que deberá regir en las aduanas de la República de Chile desde el $1^{\circ}$ de enero de 1896, Valparaíso, Imprenta del Universo de G. Helfmann, 1895, passim. 


\section{GRÁFICO N4}

IMPORTACIÓN DE SARDINAS EN LATA, 1884-1930

Miles de kilos y latas por habitante, promedio anual por quinquenios ${ }^{185}$

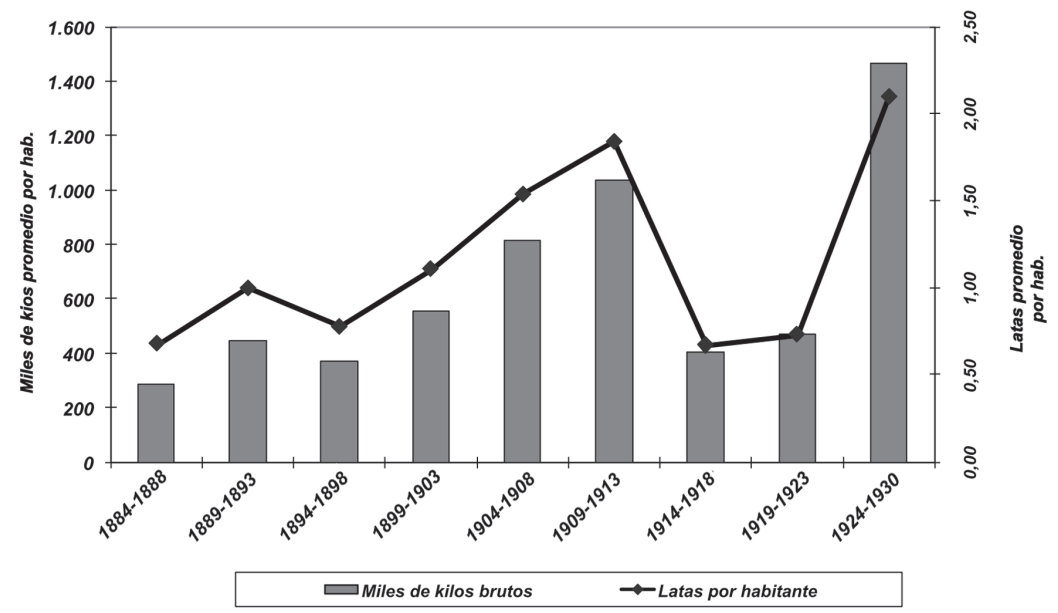

\section{GRÁFICO N 5}

IMPORTACIÓN DE SARDINAS EN LATA POR PAÍSES, 1884-1930

En miles de kilos. Años seleccionados

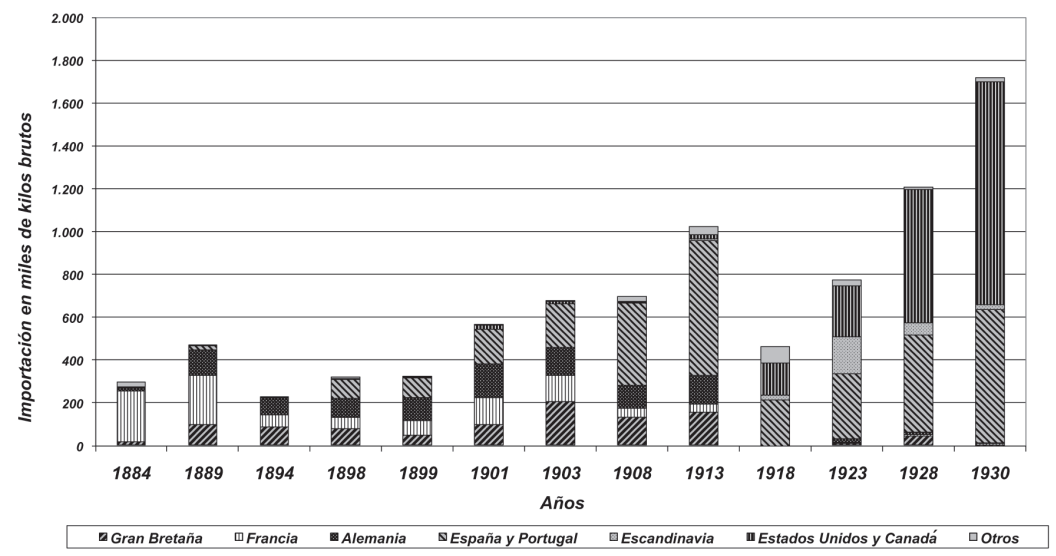

185 Estadística Comercial de la República de Chile, op. cit., 1884-1915; Anuario estadístico de la República de Chile, op. cit., 1916-1930. El peso bruto de la lata de sardinas, incluyendo caja exterior, se ha estimado en $166 \mathrm{~g}$. 
Las importaciones de salmón en lata, en agua o en aceite, aparecen desglosadas desde 1898 (gráficos № 6 y 7). Su volumen aumenta paulatinamente hasta 1912, y se mantiene más o menos estable en los años siguientes para descender a fines de la década del 20.

\section{GRÁFICO 6}

IMPORTACIÓN ANUAL DE SALMÓN, 1898-1930

En miles de kilos anuales por quinquenios ${ }^{186}$

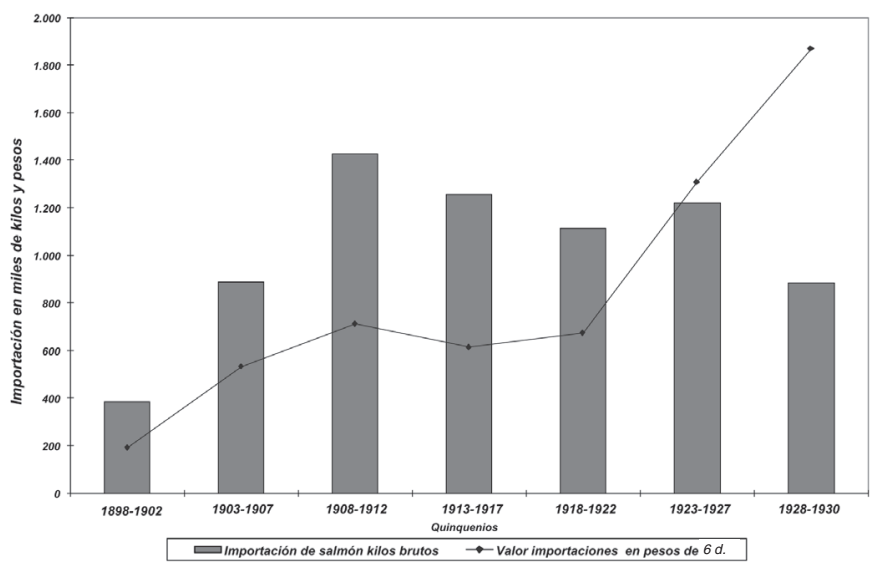

\section{GRÁFICO 7}

IMPORTACIONES DE SALMÓN POR PAÍSES, 1898-1930

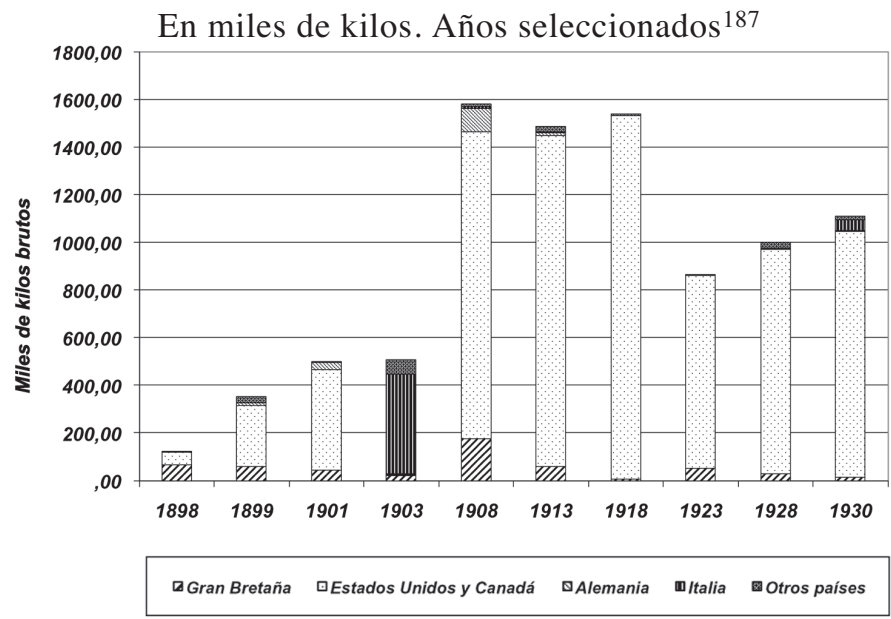

186 Estadística Comercial de la República de Chile, op. cit., 1901-1915; Anuario Estadístico de la República de Chile, op. cit., 1916-1930.

187 Idem. 
Por las dificultades ya mencionadas para su aclimatación en Chile, el salmón en conserva era de provisión más segura para banquetes y otras reuniones en que la comida debía ser programada con antelación. Su presentación era de diversas formas, incluyendo rodajas. Si embargo, el producto presentaba grandes diferencias de calidad. Un estudio sobre el tema señalaba que los salmones podían tener

"por decirlo así, dos carnes, una de color rojo antes de sus viajes de reproducción y otra descolorida a su regreso. La primera, como se sabe, es de superior calidad, de excelente sabor de contextura firme, mientras la segunda es lacia e insípida. Cualquiera ha podido comprobar en las latas de conserva esas grandes diferencias de calidad, con las que no guardan proporción las ínfimas diferencias de precio de nuestros mercados. Digamos de paso que aún el salmón rojo de las latas importadas no es tal, pues los fabricantes del otro hemisferio saben dar a la conserva destinada al nuestro el color y la apariencia ya que no el sabor, del artículo de primera, que reservan para su propio consumo"188.

La langosta en conserva importada no era tan apreciada como el producto nacional, pero se traía en cantidades relativamente grandes. Tasada a 80 cts. el kilo bruto en 1898, pagaba por entonces un derecho de internación de 48 cts., el que fue aumentado a 80 cts. en 1916 y a dos pesos en $1928^{189}$. Este incremento del impuesto explica la caída de las importaciones.

El gráfico $\mathrm{N}^{\circ} 8$ muestra el volumen y valor de las importaciones de conservas de langosta desde 1901, cuando aparecen desglosadas en las estadísticas, hasta que dejan de aparecer en 1927.

\section{GRÁFICO N 8}

\section{IMPORTACIÓN DE LANGOSTA EN CONSERVAS 1901-1930 Por quinquenios 190}

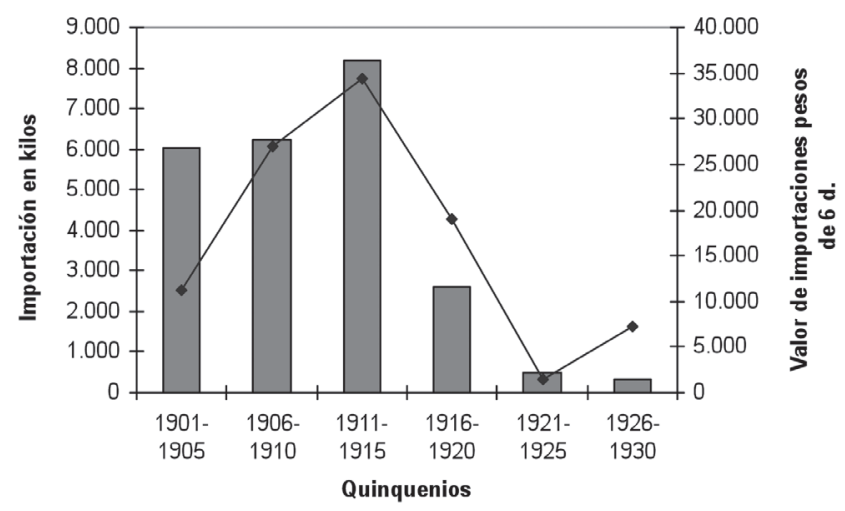

$\square$ Importación en kilos

$\multimap-$ Valor de importaciones \$ de $6 \mathrm{~d}$

188 Sage, op. cit., 302.

189 Valores en pesos de $18 \mathrm{~d}$.

190 Estadística Comercial de la República de Chile, op. cit., 1901-1915; Anuario estadístico de la República de Chile, op . cit., 1916-1930. 
En cuanto a su origen, provenían principalmente del mar del Norte (Gran Bretaña, Alemania) y de Estados Unidos y Canadá (gráfico $\mathrm{N}^{\circ}$ 9); las langostas americanas eran más pequeñas, con cinco a siete de ellas en un tarro de una libra, lo que contribuye a explicar la menor cotización de la misma191.

\section{GRÁFICO Nº}

IMPORTACIÓN DE LANGOSTAS POR PAÍSES 1901-1923

Años seleccionados

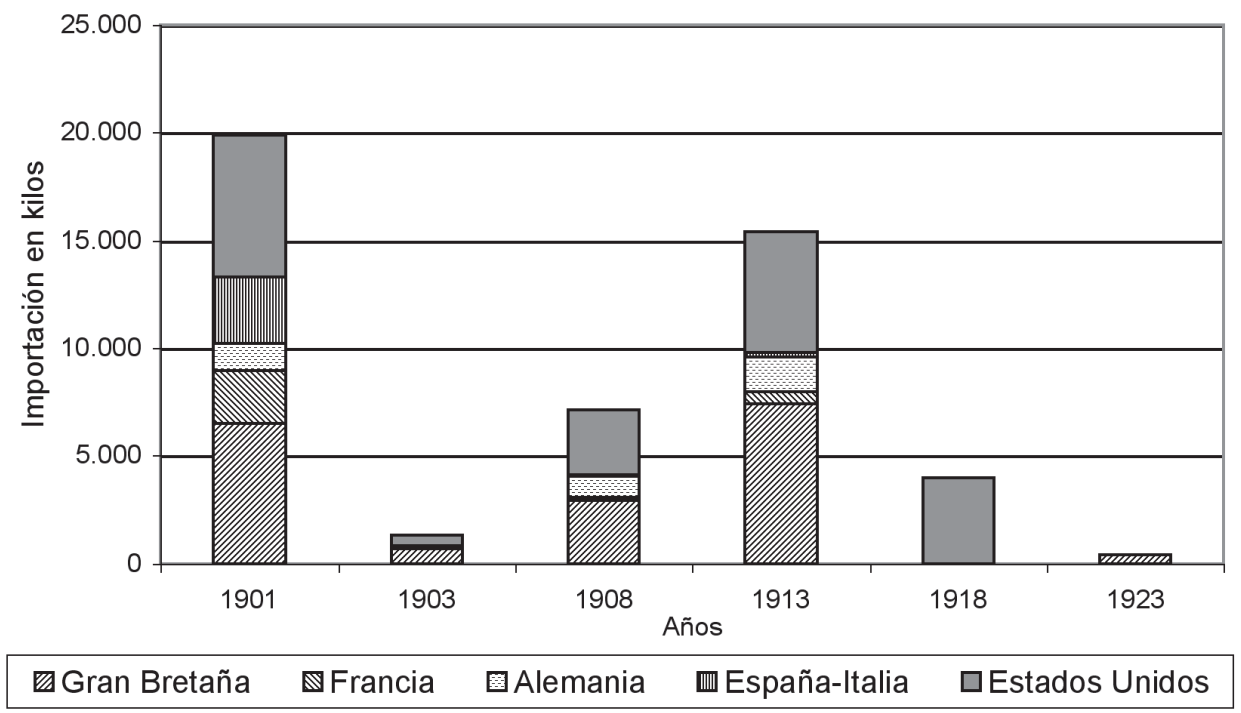

Las importaciones de otros pescados y mariscos en conserva, incluyendo el caviar, presentan una tendencia similar (gráfico $\mathrm{N}^{\circ} 10$ ). Hay una fuerte caída a partir de la Primera Guerra Mundial, y un aumento sensible en el valor unitario.

191 Almanaque pintoresco para el año bisiesto de 1872, op. cit.; Sociedad Nacional de Pesquería, op. cit., 22 . 


\section{GRÁFICO N 10}

\section{IMPORTACIÓN DE OTROS PESCADOS Y MARISCOS EN CONSERVA, 1901-1930 \\ Promedio anual en kilos y valores totales en $\$$ de 6 d..$^{192}$}

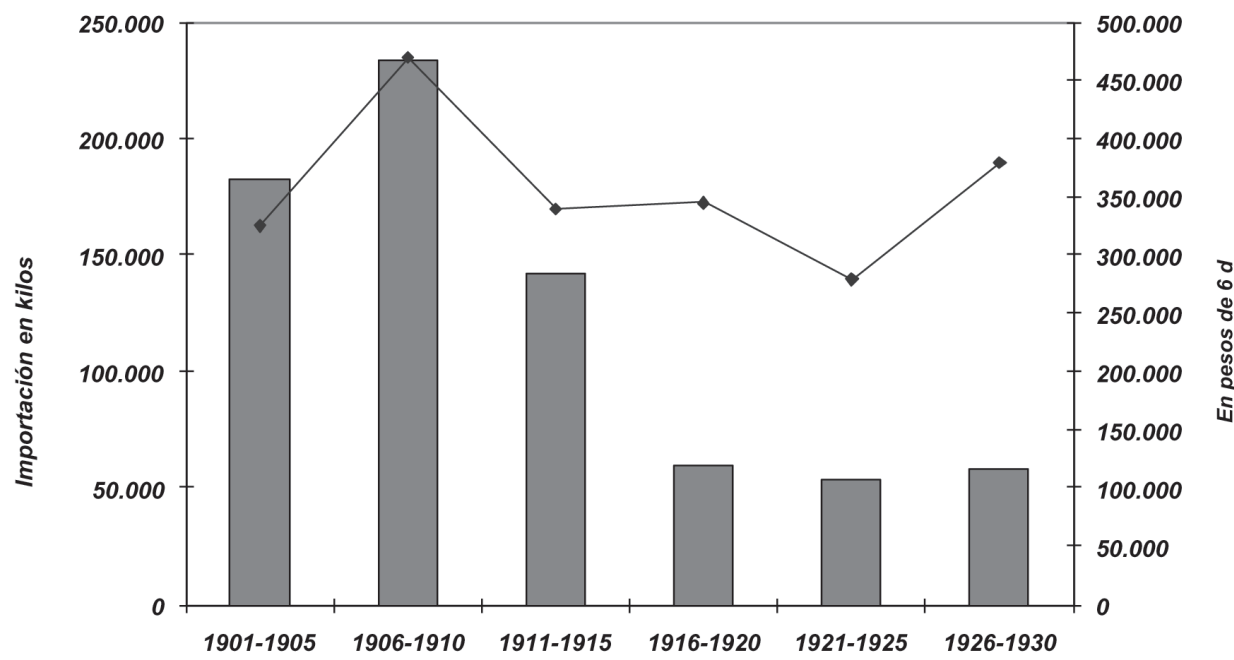

Quinquenios

Importación en kilos $\rightarrow$-Valor de las importaciones

Dentro de este rubro merece mención especial el caviar de esturión, un pez por entonces común en los ríos de Europa y Norteamérica. Al comienzo de la Primera Guerra Mundial el caviar prensado en latas era parte de la dieta de los soldados, que se resistían a consumirlo, llamándolo "dulce de pescado". El tipo más preciado era el que provenía del mar Caspio. Los trastornos políticos en Rusia a comienzos del siglo XX restringieron los suministros y entre 1900 y 1915 su precio aumentó al doble ${ }^{193}$.

El caviar aparece individualizado en las tarifas de avalúo desde 1888 con un valor aduanero equivalente a $\$ 1,30$ el kilo neto, el cual había aumentado a tres pesos para 1908. También habían subido los derechos de internación, al tratarse de un producto de lujo: de 47 centavos el kilo, se pasó a 78 centavos en 1898 y a 2 pesos el kilo en 1916. Solo existe información sobre las importaciones de caviar para fines de la década de 1920: por entonces se traía dos a tres mil kilos por año, casi todo desde Alemania ${ }^{194}$.

192 Estadística Comercial de la República de Chile, op. cit., 1901-1915; Anuario estadístico de la República de Chile, op. cit., 1916-1930.

193 Mark Kurlansky, Salt, a world history, New York, Walker and Company, 2002, 410-413.

194 Los valores están en pesos de 18 d. 
La caída en la importación de pescado y marisco fue reemplazada por la producción nacional. Según datos para mediados de la década de 1930, luego de que las importaciones fueron drásticamente reducidas y controladas por efecto de la crisis, el pescado que llegaba del extranjero representaba apenas el 1,5\% del consumo nacional, mientras que la traída de mariscos había cesado por completo ${ }^{195}$.

\section{EL CONSUMO, CALIDAD Y PRECIOS DE PESCADOS Y MARISCOS}

Pese a la longitud de las costas de Chile y la cercanía del mar, el consumo de pescados y mariscos era, y aún sigue siendo, limitado; las estimaciones y datos de producción indicados más arriba confirman este aserto. Con todo, cabe hacer un distingo: el pescado tenía buena aceptación en las zonas costeras donde se consumía fresco. Escribiendo a comienzos de los años 1830, Ruschemberger señala que los moluscos que se cogían de las rocas cercanas a Valparaíso, "se venden en el mercado de la plaza y los come la gente del pueblo"196. Mary Causten cuenta del pescado que se expendía en el mercado de Santiago: merluza, corvina, congrio, estimado como pescado fino, pejerreyes y truchas ${ }^{197}$.

Si el pescado tenía alguna aceptación en los lugares vecinos a la costa y los centros urbanos, encontraba resistencia en aquellos lugares adonde tardaba en llegar y lo hacía en malas condiciones. Un testimonio de 1913 señala:

"como el pueblo chileno lo prefiere tan fresco como pueda obtenerlo, [...] en los puertos de procedencia la producción desembarcada se vende y se consume prontamente, entre tanto que en los pueblos retirados de la costa la venta de pescado se opera flojamente y es objeto de un detenido y desconfiado examen del consumidor" 198 .

Esta actitud se mantuvo en el tiempo. Un estudio sobre las costumbres alimentarias en la zona central de Chile, de los años 1960, señala tajantemente que "el pescado es resistido en casi todas las esferas sociales" y que solo se aceptan las llamadas "especies finas", encabezadas por el congrio colorado. Por su parte, Oreste Plath agrega que en las ciudades, donde el pescado llegaba en mejores condiciones, había una mayor aceptación en los sectores populares, aunque advierte que la demanda se concentraba en el congrio y algunos mariscos y que se rechazaban muchas variedades ${ }^{199}$.

La explicación que se daba en el campo, y que este autor recoge para explicar la resistencia al mismo, es que produce urticaria porque contiene sustancias nocivas que la sangre expulsa a través de los poros, a lo que se agrega que carece de

195 Allende, op. cit., 43.

196 William Ruschemberger, Noticias de Chile, 1831-1832, por un oficial de marina de los EE. UU. de América, Santiago, Editorial del Pacífico, 1956, 20.

197 Citada por Pereira Salas, op. cit., 91. No hemos encontrado estos datos en el texto al que alude.

198 Castillo, "Conducción del pescado fresco...", op. cit., 485.

199 Alfredo Hoppe, "Apuntes para un estudio preliminar de las costumbres alimentarias de la Zona Central de Chile”, en Revista Universitaria L-LI:II, Santiago, 1965-1966, 249; Oreste Plath, "Folklore alimentario. Pescados, mariscos, algáceas”, en Mapocho V:1, 1966, 82-83. 
fuerza, que "deja el estómago vacío" y que el aspecto de su carne y su piel es semejante al de las culebras. En cambio, a los mariscos se les atribuye "un alto poder regenerador de funciones" y de ayuda para recuperar la vitalidad del hombre. Acota, empero, que se los aceptaba por su "poder vivificante" pero no por su sabor $^{200}$. Más pertinente es su observación de que el "proceso de descomposición, que es rápido por falta de transportes adecuados, hace que este producto del mar para el campesino esté asociado a la putrefacción, a cadáveres"201.

Las quejas por la calidad del pescado que se encontraba a la venta son antiguas. Un artículo en el Boletín de la Sociedad Nacional de Agricultura de 1874 comentaba: "estos peces son mortecinos, muertos asfixiados, no han desangrado, están con el germen de la putrefacción en sus carnes, como lo demuestra el olor de su descomposición" 202 .

El estudio de Dragoni y Burnet sobre la alimentación popular en Chile, elaborado en 1935, de alguna forma confirma esta resistencia al consumo. Su análisis de la composición de los almuerzos y comidas en una muestra de familias de diversos sectores a lo largo de Chile, durante catorce días, muestra que el consumo de pescados y mariscos solo tenía alguna significación en Iquique, Coquimbo y Puerto Montt, donde estos productos representaban el cinco por ciento o más de los platos servidos en su muestra. En Valparaíso, Viña del Mar, Coronel, Andacollo y en algunos grupos socioeconómicos de Valdivia y Santiago, esta proporción fluctuaba entre el uno y cinco por ciento del total de platos, mientras que en el resto del país no llegaba a esa proporción ${ }^{203}$.

No obstante dicho estado de cosas, había interés en promover su consumo. Una Cartilla de Higiene y Economía Doméstica, de 1908, utilizada en la enseñanza escolar femenina, ponderaba sus virtudes: "el pescado fresco es un alimento muy saludable y que reemplaza ventajosamente a la carne por su fuerza alimenticia"204.

Desde el punto de vista dietético, un manual de economía doméstica de 1875 estimaba preferibles los pescados cuya carne era tierna y fácil de dividir, como el pejerrey, la trucha el róbalo, el congrio, las ostras frescas y otros que son de más fácil digestión, aunque para los estómagos fuertes también eran buenos la corvina, el bacalao y otros de carne dura y apretada. La misma condición reunían algunos mariscos, como la langosta, los camarones, las jaibas y los choros ${ }^{205}$. Con todo, los manuales prevenían sobre el imperativo de consumirlos frescos: "todos los mariscos y pescados cuando no son frescos son perjudiciales para la salud" ${ }^{206}$.

\footnotetext{
200 Hoppe, op. cit., 249.

201 Idem.

202 "La carpa", op . cit.

203 Carlo Dragoni y Etienne Burnet, "L’Alimentation Populaire au Chili. Première enquête générale de 1935", apartado de la Revista Chilena de Higiene y Medicina Preventiva I:10-12, Santiago, octubre-diciembre de 1938, 85-86.

204 [Aureliano Oyarzún], Cartilla de Higiene y Economía Doméstica. Segunda edición corregida y aumentada, Santiago, Imprenta y Encuadernación Chile, 1908, 24.

205 Eduvigis Casanova de Polanco, Elementos de Economía doméstica e Higiene casera, Santiago, Imprenta y Librería del Mercurio, 1876, 41. Las mismas cualidades para los mariscos aparecen en Oyarzún, op. cit., 25.

206 Oyarzún, op. cit., 25.
} 
Una inducción al consumo de pescado durante el siglo XIX debieron ser las prescripciones de la Iglesia para el tiempo de cuaresma y otras fechas. Las normas canónicas imponían guardar abstinencia de carne todos los días viernes del año, los domingos de cuaresma y "todos los días de vijilias, témporas y cuaresma". Sabemos que, a comienzos del siglo XIX, el convento franciscano de Santiago y la Recoleta, de la misma orden, adquirían pescado seco en atados, además de pescado fresco y los mariscos, supliendo aquellos la falta de estos últimos. Las cuentas de esta última casa para el período 1817-1825, aunque parciales, muestran que el consumo de pescados y mariscos representaba un tercio del total de carnes en cuanto a valor ${ }^{207}$. Los laicos, sin embargo, podían obtener una fácil dispensa para su consumo mediante la bula de Cruzada, caso en el cual la abstinencia quedaba limitada al miércoles de ceniza, los viernes de cuaresma, los cuatro últimos días de Semana Santa y las cuatro vigilias principales. En 1899 se concedió un privilegio sobre ayuno para América Latina y en 1910 el papa Pío X suprimió las bulas de cruzada, eliminando las exigencias que la misma dispensaba, quizás porque habían caído en desuso ${ }^{208}$. Con todo, y aun suponiendo que las citadas prescripciones hayan sido respetadas por los fieles fuera de la Semana Santa, ellas no necesariamente se traducían en un mayor consumo de pescado, ya que era perfectamente posible reemplazar la carne por legumbres y otros alimentos.

Comentando sobre la oferta de pescado fresco en el mercado de Santiago en 1874, un autor menciona los pejerreyes, que se vendían entre 10 y 15 centavos cada uno conforme a su tamaño, de 20 a $30 \mathrm{~cm}$; los róbalos, de los cuales un ejemplar chico de hasta una libra (460 gramos) podía costar 20 a 30 centavos, y la trucha por la que se pagaba entre 40 y 50 centavos por dos libras (920 gramos) ${ }^{209}$.

Los precios son buen indicador de la estimación en que se tenía cada especie. Un estudio de 1900 sobre las pesquerías de Aconcagua, da cuenta de los precios de los distintos productos en la costa y en los centros de consumo. El congrio colorado eviscerado se ofrecía en tiras o cuerdas de 2 a 4 unidades, que pesaban entre 5 y 8 kilos y se vendían al equivalente de unos 20 centavos el kilo, mientras que el congrio negro, menos apreciado, costaba un 40 por ciento menos. El precio por mayor se multiplicaba por dos en los centros de consumo, y se duplicaba nuevamente al momento de su venta al consumidor. El blanquillo se vendía a 40 centavos la tira, al mismo precio que la tira de jerguillas, que pesaba de tres a cuatro kilos; la tira de pescada, con cinco o seis unidades de unos 50 centímetros de largo, salía a 50 o 60 centavos. De entre los mariscos, la langosta era el más caro, por efectos del flete y escasez: la que se compraba a siete centavos a los pescadores de

207 Rigoberto Iturriaga C., Disposiciones del Convento de San Francisco de Santiago. 1796-1828, Santiago, Archivo Franciscano, 2005, 24-60; Cristián Leal Pino, La Recoleta Franciscana de Santiago. Fuentes para su estudio. Libro de la Disposición 1805-1837, Santiago, Archivo Franciscano, 2008, 45-87. Las limosnas en corderos se calcularon a razón de un peso por animal.

208 "Instrucción o resumen de lo que principalmente debe saber el cristiano sobre el ayuno, abstinencia, bulas y privilejios de la cruzada y carne", en Almanak para el año de 1849, Santiago, Imprenta de la Independencia, 1848; Fernando Retamal Fuentes, "Presentación" en su Chilensia Pontificia, Vol. II, Tomo III, Santiago, Ediciones Universidad Católica de Chile, 2005, VII.

209 "La carpa", op . cit. 
la isla, podía llegar a costar hasta dos pesos en Valparaíso, siendo viva ${ }^{210}$. La ostra era igualmente cara por la escasez del recurso: en 1912, el saco de ostras en Ancud se vendía a ocho pesos ${ }^{211}$. La jaiba colorada o mora, que debe corresponder a aquellos admirables ejemplares que comió María Graham en Valparaíso, se vendía a 60 centavos la docena; por la jaiba blanca, más abundante y menos preciada, se pagaba una cuarta parte del precio anterior y algo menos por la jaiba peluda. El precio de los locos a la orilla de la playa era de 60 centavos el ciento, mientras que los erizos grandes era de cinco centavos cada uno ${ }^{212}$. Los precios de los pescados y mariscos en su lugar de origen aparecen particularmente bajos, pero hay que tener presente que el informante escribía con el propósito de destacar los buenos márgenes del negocio.

Con un objeto similar, el prospecto de la Sociedad Aconcagüina de Pesquería entrega una lista, reproducida en el cuadro $\mathrm{N}^{\circ} 3$, con los precios por mayor de diferentes pescados puestos en Santiago:

\section{CUADRO $\mathrm{N}^{\circ} 3$}

PRECIO DE COSTO DE PESCADO FRESCO Y PRECIO DE VENTA POR MAYOR EN SANTIAGO, $1903^{213}$

\begin{tabular}{lcc}
\hline Nombre del pescado & Precio costo kilo & Precio de venta kilo \\
\hline Pejerreyes & $\$ 0,25$ & $\$ 1,00$ \\
Trucha & 0,25 & 0,75 \\
Lisa & 0,25 & 0,70 \\
Congrio & 0,25 & 0,50 \\
Raya & 0,20 & 0,40 \\
Lenguado & 0,15 & 0,40 \\
Pescada & 0,15 & 0,40 \\
Machuelo & 0,15 & 0,40 \\
Cabinza & 0,15 & 0,40
\end{tabular}

Igualmente interesante es una nómina similar de la Sociedad Nacional de Pesquería, reproducida en el cuadro $\mathrm{N}^{\circ} 4$, que entrega los siguientes precios de venta al público en el mercado de Santiago, durante el mes de julio de 1903; los valores unitarios han sido reducidos a kilos.

210 Sociedad Nacional de Pesquería, op. cit., 23-24; Castillo, "Conducción del pescado fresco...”, op. cit., 487.

211 Meza S., "Los yacimientos de moluscos...", op. cit., 210 y sigs.

212 Wolnitzky, op. cit., 54-63. El texto en inglés da el precio en dollars que, suponemos, es la traducción de pesos. Si se tratara de moneda norteamericana, habría que multiplicar los valores por tres; Graham, op. cit., 25-26.

213 [Feliciano Soto Valenzuela], Estatutos de la sociedad aconcagüina de pesquería y conservas de peces y mariscos, Santiago, Imprenta El Progreso, 1903, 3. 
CUADRO $\mathrm{N}^{\circ} 4$

PRECIOS DE VENTA EN EL MERCADO DE SANTIAGO REDUCIDOS A PESOS POR KILO ${ }^{214}$

\begin{tabular}{lc}
\hline Clase de pescado & Precio por kilo \\
\hline Pejerrey & 2,50 \\
Lisa & 2,00 \\
Trucha & 1,90 a 2,00 \\
Corvina & 1,40 \\
Raya & 1,20 \\
Congrio & 1,00 \\
Lenguado & 0,70 \\
Pescada & 0,60 \\
Machuelo & 0,60 \\
Cabinza & 0,60
\end{tabular}

De acuerdo a esta última fuente, se indicaba para efectos comparativos que la carne de buey y de cordero se vendía entre 70 y 90 centavos el kilo. La ventaja en favor de las carnes rojas es tanto mayor si se piensa que no hay pérdida por cabeza, cola, espinazo, piel y escamas.

Las conservas de mariscos en envases de hojalata reflejaban esta situación. Las de Solminihac se vendían por entonces en Santiago a los siguientes precios:

$\begin{array}{ll}\text { Choros al natural } & \$ 0,45 \\ \text { Choritos al natural } & \$ 0,40 \\ \text { Tacas } & \$ 0,40 \\ \text { Locos } & \$ 0,50 \\ \text { Picos } & \$ 0,50 \\ \text { Erizos } & \$ 0,55 \\ \text { Choros en aceite } & \$ 0,55 \\ \text { Choritos en aceite } & \$ 0,50^{215}\end{array}$

El precio relativamente alto del pescado resultaba un desincentivo a su consumo. De ahí la iniciativa de la Dirección de Pesca y Caza en 1913, a través de Luis Castillo, que logró que la Municipalidad de Santiago destinara "vastos locales en el Mercado Central para que en ellos se expenda pescado fresco directamente al consumidor", como una manera de abaratar su precio reduciendo la ganancia de los intermediarios. Una iniciativa parecida se llevó a cabo en Valdivia, donde el alcalde se comprometió a proporcionar un espacio gratis a los vendedores que "se

214 Sociedad Nacional de Pesquería, op . cit., 33.

215 Maldonado, op. cit., 172. 
comprometan a vender solo al menudeo antes de las 8 de la mañana", pasada la cual se cobraría derecho de piso. Los resultados, al parecer, fueron altamente satisfactorios $^{216}$

Otro indicador de la demanda por los distintos productos de mar es el agotamiento del recurso y la necesidad de controlar su explotación. Es lo que sucedió con los pejerreyes y cauques de Aculeo, los choros zapato de la isla Quiriquina, la langosta de Juan Fernández y las ostras de Chiloé y Llanquihue, aunque en este último caso el problema radicaba en su deficiente explotación antes que en la extracción excesiva.

Como vimos, el pescado más apreciado era el pejerrey, el que se anunciaba como un plato especial en el Hotel Dorado de Valparaíso, en $1886^{217}$. Luis Castillo ponderaba sus virtudes: el pejerrey frito no tiene "rival alguno a juicio de todo el mundo", aunque también resultaba sabroso cuando se preparaba estofado en fuente, en caldillo o cocido en salsa de mantequilla ${ }^{218}$. William Howard Russell declara que "nadie está mucho tiempo en Chile antes que se le pida que alabe el pejerrey", si bien él personalmente lo encontraba desabrido: "es como un gobio de gran tamaño, y cuando se abre por la mitad y se fríe no es del todo insípido; tiene algo del sabor, o de la falta de sabor, de la pescadilla [whiting]"219.

Al otro extremo del espectro, entre los pescados baratos, estaban la pescada o merluza, la más abundante y que, por lo mismo, figura en algunos recetarios, como veremos más adelante. A esta se agregan el machuelo, la cabinza y la sierra, la cual no aparece en los cuadros 2 y 3 , pero es mencionada en el mismo sentido ${ }^{220}$.

De los mariscos, el más apetecido, junto con la langosta de Juan Fernández, era la ostra, en particular la ostra del sur. Escribiendo en la década de 1820, María Graham dice: "de las provincias del sur se trae con frecuencia una abundante variedad de ostras" 221 . Aunque no aparezcan individualizadas en las estadísticas de cabotaje, los buques de carrera de las principales compañías navieras que recalaban en Ancud -los de la Compañía Inglesa, Braun y Blanchard, Kosmos y otrascargaban ostras frescas para llevarlas a los puertos del norte, adonde llegaban en muy buenas condiciones. William Howard Russell cuenta que al recalar en Tomé un vapor de cabotaje, subieron a bordo varios caballeros para preguntar por sus embarques del molusco ${ }^{222}$. En Valparaíso estas solían conservarse frescas en depósitos artificiales de agua de mar, usando para ello embarcaciones surtas en la bahía. También se hacían embarques con destino a Santiago vía Talcahuano, desde donde eran despachadas por ferrocarril ${ }^{223}$. Los mariscos conservados en los depósitos de

216 "Abaratamiento del pescado", en $B B P C$ I:12, mayo de 1913, 788-789; "Pescado municipal barato", en BBPC I:5, noviembre de 1912, 356-357.

217 Guía y Almanaque comercial de Valparaíso para 1886, Valparaíso, Imprenta La Patria, 1886,70 .

218 Castillo, "Contribución... (I)", op. cit., 38-39.

219 Russell, op. cit., 143.

220 Mardones y Cox , op. cit., 89.

221 Graham, op. cit., 42.

222 Russell, op. cit., 62.

223 El Mercurio, Santiago, 3 de junio de 1905, 2. 
Valparaíso podían ser consumidos dentro del período de veda dispuesta por la ordenanza de 1874, que regía entre el 1 de octubre y el 1 de mayo. Se exigía, empero, que las ostras hubieran sido traídas allí durante los meses de libre consumo y que los depósitos estuvieran situados en los lugares de la bahía especialmente designados 224 .

Russell estimaba que las ostras chilenas eran algo menos sabrosas y rellenas que las de Ostende, pero de ningún modo despreciables 225 . Por su parte, George Morant, que visitó Chile en 1891, comentaba que en Valparaíso las ostras eran abundantes y sabrosas, aunque pequeñas, mientras que la citada Cartilla de Higiene y Economía Doméstica declaraba que estas eran el marisco "de más fácil digestión"226.

Claudio Gay declara que la ostra chilena tiene un gusto tan rico como las de Francia, pero agrega, consternado, que "los habitantes solo la comen cocida"227. Samuel Greene Arnold registra una experiencia similar en 1848, pues declara haber comido "ostras guisadas en una olla, como algo muy apreciado en estas regiones" 228 . Los hábitos parecen haber cambiado, pues una observación de Russell hace pensar que se comían crudas: "se contraen terriblemente al entrar en contacto con jugo de limón o vinagre, pero aun las damas más finas y delicadas no se desaniman por estas expresiones exteriores y visibles de sufrimiento y las comen con gusto" 229 .

En la década de 1880 había en Santiago varios locales especializados en ostras, como el restaurante de M. Tirraud, en calle Ahumada, el de Adolfo Dreckmann, en Estado 19 A, y el Gran Hotel Los Hermanos, de Agustinas con Ahumada, que en 1884 avisaba que tenía "constantemente ostras frescas a cualquiera hora del día". Más tarde aparece el Salón de Ostras de Luis Marlas, en Ahumada 55230. Ya en 1918, nos encontramos con el restaurante La Playa de Tort Hermanos, en Monjitas 826, que además de ostras de Ancud a \$ 1,50 el plato, ofrecía choros, locos en salsa verde a \$1,20 y \$1,40 la porción, y erizos de San Antonio y Algarrobo, recogidos por "buzos que solo pescan para este establecimiento" 231 .

224 Ordenanza del Intendente de Valparaíso, 7 de agosto de 1874, en Decretos Municipales y Administrativos de Valparaíso, Valparaíso, Imprenta del Mercurio, 1876, Tomo II, 183-184; Decreto de la Intendencia de Valparaíso de 19 de agosto de 1874, en Disposiciones Municipales. Leyes, Ordenanzas..., op. cit., 1912.

225 Russell, op. cit., 62.

226 George C. Morant, Chili and the River Plate in 1891. Reminiscences of Travel in South America, London, Waterlow \& Sons Ltd., 1891, 135; Oyarzún, op. cit., 25.

227 Gay, Zoología, VIII, op. cit., 281-288. Véase también su Atlas, II, op. cit., lámina "Malacología 5", figuras 1 a 3; Pomar, op. cit., 25.

228 Samuel Greene Arnold, Viaje por América del Sur, Buenos Aires, Emecé Editores, 1951, 242.

229 Russell, op . cit., 62.

230 Julio Vicuña Cifuentes, "Recuerdos santiaguinos", en Revista Chilena de Historia y Geografía 90, Santiago, 1937, 80; El Almanaque-Guía de la Imprenta Victoria para el año bisiesto de 1884, Santiago, Imprenta Victoria, 1883, 30; Guía Trimestral Chilena de la Imprenta Roma, Santiago, Imprenta Roma, 1897, Sección "Santiago por Gremios”, 72.

231 Pacífico Magazine 64, abril de 1918, citado por Pablo Díaz Mery, "La comida y cocina en Pacífico Magazine 1913-1921”, Trabajo de Seminario, Instituto de Historia Pontificia Universidad Católica de Chile, 2003, 49. 


\section{LOS RECETARIOS Y LOS BANQUETES}

La revisión de los libros de cocina de la época permite formarse una idea sobre los pescados y mariscos de mayor presencia en la mesa y las formas empleadas para su preparación.

El Arte Gastronómico de 1851 contiene tres recetas de pescado, ninguna de las cuales indica una especie en particular. Estas se referían al pescado borracho, al pescado al vino y al "pescado frito en salsa de pan", donde, conforme se desprende de las indicaciones, lo frito no era el pescado sino las papas que lo acompañan. De las dos recetas que emplean mariscos, una es una salsa para ostiones y la otra unos "pastelitos de jaiba", la que va incluida entre los postres y que, por la inclusión de azúcar en su preparación, parece tener cierta antigüedad: "se cuecen las jaibas, se les saca la comida i se tiene un poco de cebolla picada, huevos duros, pasas, aceitunas, azúcar, canela; con todo esto llenan las jaibas i se ponen un batido de huevos con harina i azúcar, i después se fríen"232.

Al comparar este recetario con el Nuevo Manual de Cocina del Libro de las Familias, aparecido en 1882, se observa que el número de preparaciones de pescados o mariscos alcanzaba a 61, un aumento congruente con la mayor jerarquía de la obra $^{233}$. En El Cocinero Práctico Chileno, editado el año siguiente, las recetas con pescados y mariscos ascendían a 82 en total. Se repetían las cinco recetas de 1851 y se agregaban otras 77 . De estas, 56 eran de pescado, 13 de mariscos y tres de sopas, otras tres correspondían a rellenos para aves y dos a salsas de anchoas y de ostiones, respectivamente. La mayoría de las recetas especifican los pescados y mariscos que deben utilizarse; es así como para los pescados hay 11 recetas de bacalao y otros pescados secos, siete para truchas y cinco para las anguilas; el salmón (fresco o seco), el lenguado y los pejerreyes tienen cuatro recetas cada uno, hay dos recetas para la corvina y el congrio, más una para cualquiera de ambos, la sardina, el róbalo y la sierra tienen una receta cada uno y hay otras once recetas genéricas. Aunque es posible inferir cierta relación entre el número de recetas para cada variedad de pescado y el mayor o menor consumo de estos, es probable que ello dependa también en buena medida de los recetarios europeos copiados. En cuanto a las preparaciones, destaca la diversidad de las mismas: los hay asados, cocidos, al horno, fritos y en pasteles; podían servirse enteros, trozados, enrollados, en albóndigas o rellenos; hay frecuentes menciones al empleo de aceite -aunque para freír se usaba grasa o manteca-, de limón, de vinagre y también de vino. Al parecer, aunque no se especifica, todas las preparaciones se servían calientes.

232 Arte Gastronómico. Resetas [sic] de guisos i potajes para postres, Segunda edición considerablemente aumentada, Santiago, Imprenta del Estado, 1851, 11-12, 14 y 30.

233 El Libro de las Familias. Nuevo Manual de Cocina conteniendo 377 recetas de guisos escogidos de las cocinas francesa, española, chilena, inglesa e italiana, arreglado para el uso de las familias del país. Nueva edición aumentada, Valparaíso, Librería del Mercurio de Orestes L. Tornero, 1882, especialmente 24-34. 
En cuanto a los mariscos, seis de las preparaciones se refieren a la ostra, siendo una de ellas una salsa para rellenar capones; en todos los casos este marisco iba previamente asado o cocido. El hecho de que no se mencione la ostra fresca al natural no implica que no se comiese también cruda, como anota Russell, ya que para ello no se requería de una preparación especial. Hay tres recetas para choros -cocidos, asados y en pastel- y dos para picorocos. Otros mariscos mencionados son las langostas (frescas o en conserva), los erizos, los camarones, las jaibas y los ostiones ${ }^{234}$.

Tanto los pescados como los mariscos solían ir acompañados de salsas, incluyendo dos de mostaza (aunque una de ellas no incluye dicho ingrediente), un producto que recién en 1859 figura en la nómina de importaciones ${ }^{235}$. Llama la atención la receta para un "chupe de Lima" con camarones, pero que también se podía hacer con pejerreyes frescos, ostiones y langosta fresca; dado que la receta no contiene limas ni otros cítricos y emplea papas en lugar de pan, se trata de un chupe a la manera como se prepara en el Perú, lo que apunta a una influencia de la cocina de ese país en Chile que coincide con la Guerra del Pacífico ${ }^{236}$.

La Enciclopedia del Hogar de la Tía Pepa de Rafael Egaña, publicada en 1899, contiene un número inferior de recetas de pescados y mariscos, alrededor de 40. La nómina de productos no varía demasiado de la obra analizada anteriormente: anguilas, bacalao, congrio, corvina, róbalo y truchas entre los primeros; choros, choritos, langosta en conserva, camarones, picos, ostiones y locos entre los segundos. El libro representa un avance respecto a los anteriores, por la mayor sofisticación de las preparaciones, reflejo de la cultura gastronómica de su autor. Una novedad es la receta para marinar arenques, ya que "los arenques salados o ahumados -única forma en que nos llegan- no tienen gran consumo, sobre todo porque no se conocen muchas formas de prepararlos" 237 .

Más significativa es la inclusión de algunas preparaciones clásicas de la cocina internacional: el lenguado a la normanda, la salsa tártara para el congrio frito, la mantequilla negra y las salsas bechamel y holandesa para el bacalao. Aquí la mantequilla aparece como un ingrediente mucho más frecuente en las recetas, influencia clara de la cocina francesa ${ }^{238}$. El mayor número de recetas de pescados y mariscos para esta época parecería estar en La Cocina Moderna y Práctica de Lucía Vergara de Smith, de 1912. Llama la atención las muchas preparaciones peruanas: hay dos para el chupe de locos, las que requieren el uso de "ají peruano"; una tercera de "picante de ostiones", otra de "pescado a la chorrillana", cuyo ají "tiene que ser peruano", y finalmente una para cebiche de corvina, que difiere levemente de la preparación actual: "se corta [el pescado] en tajaditas delgadas y

234 Nuevo manual del Cocinero Práctico Chileno..., op. cit., 8-9, 24-43 y 55.

235 Ibid., 36 y 38.

236 Ibid., 28; El libro de las familias..., op. cit., 29-30. Estas influencias posbélicas hacen pensar en los picarones de la negra Rosalía, a los que alude Pereira Salas.

237 Rafael Egaña, Tía Pepa, Enciclopedia del hogar: cocina, repostería, helados, bebidas, licores, tocador, medicina e hijiene, homeopatía, economía doméstica, Santiago, Imprenta y Encuadernación Esmeralda, 1899, 23.

238 Ibid., 62-79. 
se le agregan rajas de cebolla, se le espolvorea sal fina y se cubren con jugo de naranja agria y ají mirasol. Se deja el pescado por cuatro horas"239.

La misma autora, en su libro Cordon Vert destinado a las dueñas de casa, entrega menús completos de tres a cinco platos más postre para distintas ocasiones, algunos de los cuales contienen preparaciones simples y sin demasiadas pretensiones. La incidencia de pescados y mariscos en esos menús resulta de interés, aunque puede tratarse de una expresión de deseo antes que una muestra de preferencias domésticas efectivas. De los 19 menús para almuerzos, 13 incluyen pescados o mariscos; la proporción baja a algo más que la mitad, 4 de 11 menús, en el caso de los almuerzos diarios, pero sube a 17 de los 20 menús de comidas, porque estas incluyen un plato más. Lo que sí resulta significativo es que siete de los nueve "menús baratos" incluyan algún pescado, aunque no mariscos, quizás por el menor precio de aquellos respecto de las carnes. En síntesis, de 70 menús sugeridos, 50 -un 70 por cientoincluyen pescado o marisco. De los pescados identificados, el más común es el lenguado, seguido por los pejerreyes y el bacalao, mientras que entre los mariscos aparecen con mayor frecuencia los choros, las ostras y los erizos ${ }^{240}$.

Una muestra similar la proporciona Marta Brunet en su libro La hermanita hormiga, que incluye propuestas de menús para el almuerzo y comida por treinta días. Los menús de almuerzo constan de tres platos y postre; los de comida de cuatro platos, incluyendo una sopa, y además un postre. De estas 60 meriendas, 33 incluyen algún pescado o marisco; hay ocho días en que se contempla pescado o marisco tanto al almuerzo como en la cena y solo cuatro días en que no se los considera del todo en los menús. De los pescados identificados, los que aparecen con mayor frecuencia son la corvina, el lenguado, la pescada y la trucha ${ }^{241}$. Esta participación del pescado, y en menor grado de los mariscos, en los menús propuestos por Vergara y Brunet se explica por el número de platos considerados para cada merienda y la necesidad de dar variedad a la oferta.

Otra manera de aproximarse al consumo de pescados y mariscos y las formas de su preparación son los menús de banquetes y recepciones. En general se trata de grandes ocasiones, aunque también hay menús para reuniones más informales, como una comida de oficina o un almuerzo familiar. También aquí se ofrece una diversidad de platos, especialmente en los banquetes de gran concurrencia y, ante la necesidad de dar variedad, casi siempre hay un servicio de pescados y mariscos.

De una muestra de 370 menús entre 1874 y 1930, 339 consideran un servicio de pescado o marisco, un número que aumenta si se considera la oferta de ostras, anchoas y otros productos del mar entre los hors d'oeuvres con que se inicia la comida. El gráfico $\mathrm{N}^{\circ} 11$ muestra la distribución de pescados y mariscos en los menús considerados. La suma de los distintos ítems es superior al total, porque en algunos casos se ofrecen dos platos con productos de mar.

239 Lucía Vergara de Smith, Cocina Moderna y Práctica, Santiago, Talleres de la Imprenta ZigZag, 1912, 81-121. El ají Mirasol parece haber sido el equivalente del ají peruano.

240 Lucía Vergara de Smith, Cordon Vert. Menús para almuerzos y comidas. Cocktails, Santiago, Empresa Zig-Zag, 1914, passim.

241 Marta Brunet, La hermanita hormiga, Tratado de arte culinario, Santiago, Editorial Nascimento, 1931, 487-492. 


\section{GRÁFICO N 11}

CONSUMO DE PESCADOS Y MARISCOS EN BANQUETES, 1874-1930

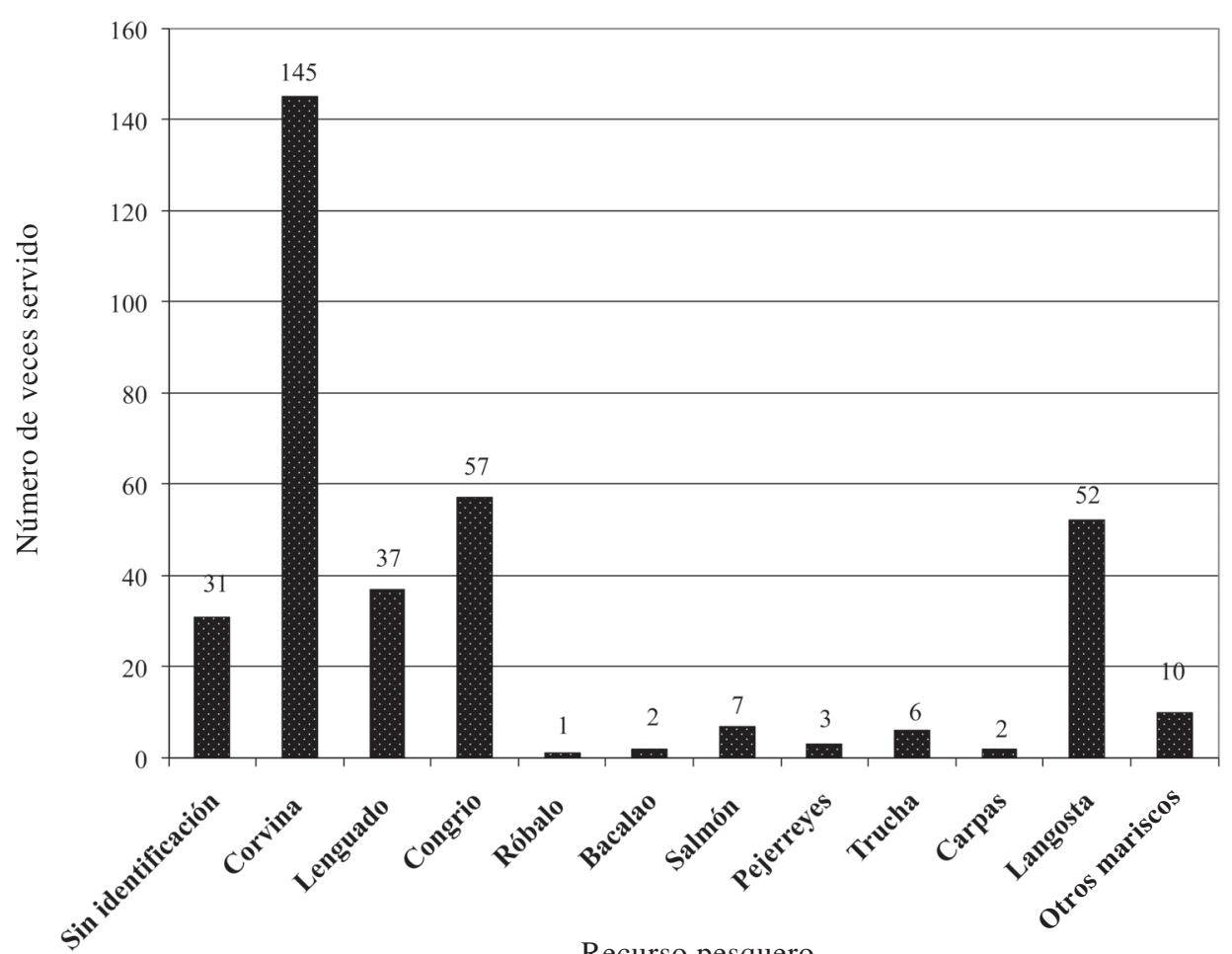

Recurso pesquero

Como se aprecia, la corvina es el pescado que figura con mayor frecuencia, aunque desde 1919 se observa un predominio del congrio. El mayor consumo de este último pescado, que continúa en la década de 1930, guarda relación con su mayor presencia en nuestras $\operatorname{costas}^{242}$. El lenguado, denominado indistintamente sole o turbot, ocupa el tercer lugar en las preferencias. Las carpas solo aparecen en 1897 y la trucha -no sabemos si la de cultivo o la criolla- solo figura entre ese año y 1905 , lo que confirma que los proyectos de piscicultura no prosperaron en el tiempo. En cuanto a los mariscos, la langosta es el que aparece con mayor frecuencia en el servicio de pescado. La langosta también se ofrecía como hors d'oeuvres, al igual que las ostras y algunos productos importados como el caviar, las anchoas

242 Mardones y Cox, op. cit., 89. Aunque el libro fue publicado en 1942, las cifras que entrega son de la década de 1930 . 
y las sardinas. De acuerdo a los menús revisados, el consumo de ostras se concentra entre mayo y agosto, los meses sin " $r$ " de clima más frío, aunque hay casos en que se ofrecen fuera de temporada.

\section{CONCLUSIONES}

Como hemos visto, la identificación de los pescados ofrecidos para el consumo resulta más imprecisa de lo que suele ser hoy: un mismo nombre era aplicado a distintas especies y una misma especie era conocida con distintos nombres. Se solía vender una variedad de pescado por otro, sea por ignorancia o de manera deliberada para obtener mejor precio. Vistas las dificultades que presenta la clasificación de las especies, no es de extrañar que se produjeran estas situaciones. Esta asimilación se producía también con el pescado seco y las conservas importadas, como era el caso del bacalao o la langosta. Contribuían a estos equívocos las equivalencias, para efectos gastronómicos, de peces chilenos y europeos, de caracteres de similares pero de especies diferentes.

No obstante la diversidad de peces existente en nuestro mar, el consumo estaba concentrado en unas pocas especies, en general más finas. No se aprecian demasiadas variaciones en las preferencias a lo largo del tiempo, excepciones son la lisa y el róbalo, ponderados por los cronistas pero casi sin figuración en los recetarios y menús de comienzos del siglo $\mathrm{XX}$; en cuanto a la mayor presencia del congrio por el mismo período, parece ser el efecto de su mayor disponibilidad. Algo semejante sucedía con los mariscos, cuya deficiente explotación o sobreexplotación contribuyó a la escasez del recurso y, en el caso de las ostras, a su cultivo en viveros. El éxito con las ostras no se replicó en la langosta ni en la piscicultura, pese a los esfuerzos desarrollados en este sentido. Los salmones y truchas introducidos en los ríos y lagos del sur no se multiplicaron en la forma prevista, en parte, por la forma como se llevaba a cabo la pesca de los mismos. Su desaparición de los menús confirma lo anterior.

Los antecedentes respecto al consumo de pescado y mariscos son fragmentarios, pero todos apuntan a un aumento durante el período estudiado. La tendencia se aprecia a través de las mayores importaciones de productos de la pesca en la década de 1890; en el mayor número de personas dedicadas a esta actividad; el desarrollo de una industria pesquera más eficiente y de mayor alcance, en cuanto se extiende a alta mar, y en las mayores facilidades para su transporte, que repercuten en un producto más fresco y por ende más atractivo para el consumidor. En todo caso, hay que tener presente que, por razones de disponibilidad y frescura del producto, la demanda se concentraba mayormente en los puertos y ciudades donde las facilidades de transporte son mayores. Por lo mismo, es muy posible que el mayor consumo esté relacionado con el aumento de la población urbana respecto a la rural y la consiguiente facilidad para acceder a los productos del mar.

La creciente figuración de pescados y mariscos en los recetarios y la mayor variedad de formas de prepararlos que entregan los manuales de cocina, efecto de una influencia europea y aun peruana, apuntan a su mayor presencia en la mesa. Su 
inclusión en los menús de banquetes y comidas, si bien no necesariamente refleja un consumo generalizado entre la población, sí tienen un carácter modélico que repercute en el mismo sentido. Por último, las encuestas sobre la incorporación del pescado en la dieta de la población permiten cuantificar, con algún viso de seriedad, esta tendencia.

El mayor consumo de pescados y mariscos es una expresión de la mayor variedad en la alimentación de los chilenos durante este período, e implica una paulatina adaptación de los paladares locales a sabores desacostumbrados o nuevos. El fenómeno, por cierto, no está limitado a la esfera de la comida y la bebida, sino que se observa también en el caso de otros bienes de consumo, como el vestuario o los utensilios domésticos, y es parte de los cambios en la cultura material del país, producto de la mayor apertura de Chile al mundo durante su primer siglo de vida independiente. 
